\title{
cepe
}

Centre for Energy Policy and Economics

Swiss Federal Institutes of Technology

\section{Modeling Technology Adoption as an Irreversible Investment Under Uncertainty: The Case of the Turkish Electricity Supply Industry}

Reinhard Madlener, Gürkan Kumbaroglu, Volkan Ediger

\section{CEPE}

ETH Zentrum, WEC 



\title{
Modeling technology adoption as an irreversible in- vestment under uncertainty: the case of the Turkish electricity supply industry ${ }^{1}$
}

\author{
Reinhard Madlener ${ }^{\mathrm{a},{ }^{*},}$ Gürkan Kumbaroğlu ${ }^{\mathrm{b}}$ and Volkan Ş. Ediger ${ }^{\mathrm{c}, 2}$ \\ a Centre for Energy Policy and Economics (CEPE), Swiss Federal Institute of Technology Zurich, ETH Zentrum \\ WEC, CH-8092 Zurich, Switzerland \\ b Department of Industrial Engineering, Boğaziçi University, TR-34342 Bebek, Istanbul, Turkey \\ c Cumhurbaşkanlı̆̆ı, Çankaya, TR-06689 Ankara, Turkey
}

CEPE Working Paper No. 30

February 2004

\footnotetext{
1 An earlier version of this article was presented at the 2003 International Conference on Policy Modeling (EcoMod 2003), 3-5 July 2003, and the EURO/INFORMS 2003, 6-10 July 2003, both held in Istanbul, Turkey.

*Corresponding author. Tel.: +41-1-632 0652; fax: +41-1-632 1050. E-mail address: madlener@cepe.mavt.ethz.ch .

${ }^{2}$ Volkan Ediger also teaches at the Geological Engineering Department, Middle East Technical University (METU), Ankara.
} 


\section{Table of Contents}

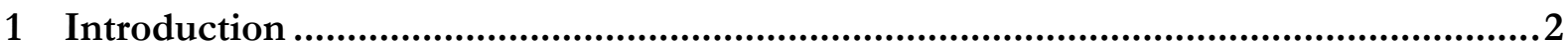

2 Electricity system capacity (expansion) planning and the adoption of power generation technologies..

3 Literature review and theoretical approaches considered..........................................4

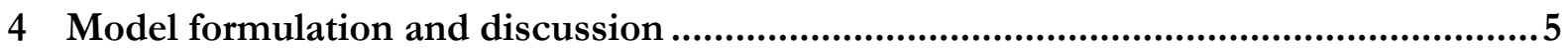

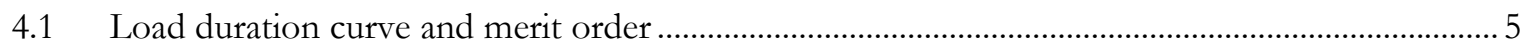

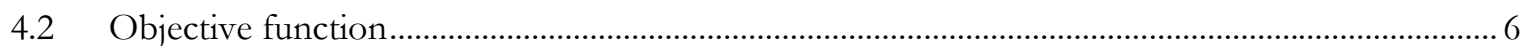

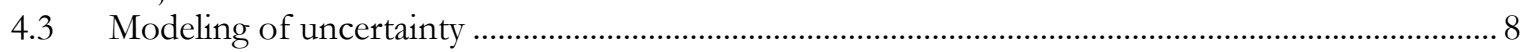

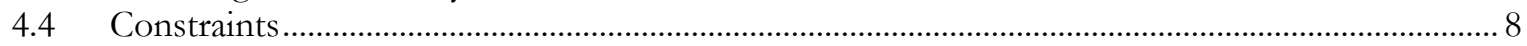

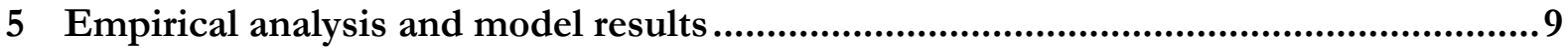

5.1 Electricity demand and supply in Turkey ................................................................................

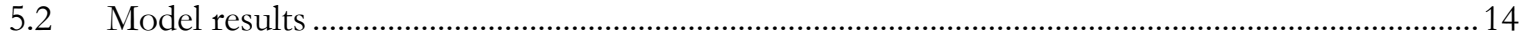

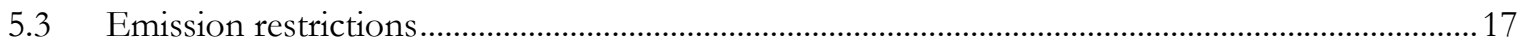

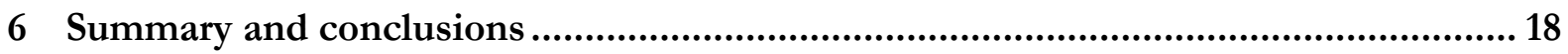

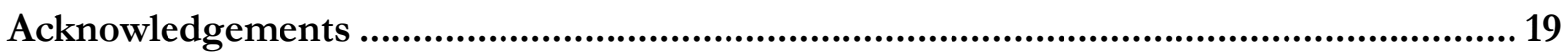

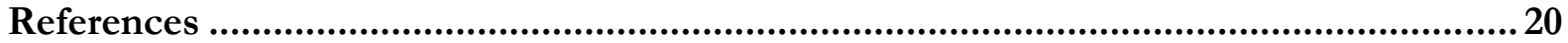

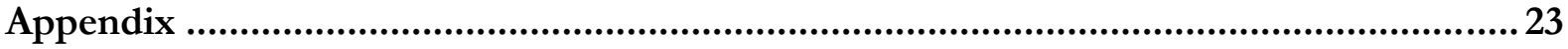




\begin{abstract}
This paper studies energy conversion technology adoption in the electricity supply sector from the perspective of irreversible investments under uncertainty, and with a particular interest in environmental sustainability. We develop a dynamic technology adoption model that is firmly rooted in economic theory and that takes important determinants of optimal investment in available technologies (e.g. life-cycle capital and operation cost) explicitly into account. Uncertainty is introduced for the demand for peak-load capacity, unit generation costs, and for the average electricity price. We test the model empirically by applying it to data for the Turkish power supply industry. The model-guided optimal investment results based on net present value considerations exhibit significant deviations from the actual investment outcome. We find that the increased adoption of natural-gas-fired power generation technologies in Turkey in recent years, while contributing to environmental sustainability, has had doubtful merits from an investor's perspective.
\end{abstract}

Keywords: Technology adoption; Irreversible investment under uncertainty; Real options; Electricity supply; Dynamic optimization 


\section{Introduction}

Increasing concern about the adverse socio-economic and environmental impacts of current energy use patterns, in many cases coupled with staggering levels of fossil fuel import dependence, call for substantial changes in the energy technology and fuel mix towards a more sustainable energy supply system. Technology adoption and diffusion models (e.g. Thirtle and Ruttan, 1987; Sarkar, 1998), both at the micro-economic and the aggregate level, can provide valuable insights for a better understanding of actual and required transitions in the energy-converting capital stock composition, related fuel consumption patterns, underlying investment decisions, and technological trajectories followed.

In this paper we study energy conversion technology adoption in the electricity sector from the perspectives of irreversible investment under uncertainty and environmentally sustainable development. Particularly, we develop a dynamic technology adoption model that features elements from real options theory (Dixit and Pindyck, 1994), and apply it to detailed industry-level time series cross-sectional data for Turkey (e.g. for installed capacities, unit generation costs, fuel input and electricity consumption and prices). The model developed is firmly rooted in economic theory and rests on important determinants of investment in available technology options, such as (expected) capital and operation costs over the lifetime of a certain vintage of a specific technology.

Investment decisions in liberalized markets, in contrast to non-competitive markets, are based on market-driven value maximization criteria. Because the profitability of investment projects is contingent upon input and output price variations, project values evolve dynamically over time. Therefore, it is optimal to invest in some physical asset ('real option') when the present value of the expected cash flow exceeds the cost of investment by a (strictly) positive amount that is at least equal to the compensation for the loss of forfeiting the real option.

Two alternative approaches are discussed in the literature to derive the optimal investment rule and the value of the optimal investment in a real asset. While contingent claims analysis is essentially rooted in the finance literature, dynamic programming starts from a given discount rate and considers the maximization problem of the expected value of discounted cash flows. The two methods are linked through the equivalent risk-neutral valuation principle, and although they make different assumptions about financial markets and the rates firms use to discount future cash flows, they yield identical results in many applications. In contingent claims analysis one attempts to find some combination or portfolio of traded assets that will be an exact replication of the return and risk pattern pertaining to the investment project studied. In this paper, a dynamic programming approach is adopted and the timing of the irreversible investment formulated as an optimal stopping problem (e.g. Karatzas and Shreve, 1991). In particular, we use a model that accommodates plant availability, load duration curves, and irreversibility of investment, similar to that of Moreira et al. (2004) and Chaton and Doucet (2003). This allows us to analyze the investment decisions taken for different vintages of power generating technologies based on different energy resources.

The Turkish electricity supply industry provides the subject of our empirical analysis. Power plant expansion planning in Turkey has so far been based on the two main models MAED ${ }^{2}$ and

\footnotetext{
${ }^{2}$ Model for Analysis of Energy Demand; a simulation model that has been operated by the Turkish Ministry of Energy and Natural Resources since 1984.
} 
WASP $^{3}$, whose shortcomings have been discussed in various studies. For example, an investigation of historical MAED/WASP projections indicates that the model results have persistently overestimated electricity demand, as documented in Ediger and Tatlidil (2002). Arıkan and Kumbaroğlu (2000) highlight the importance of the energy-economy feedback link that is missing in the MAED/WASP approach.

We discuss our model's characteristics and compare its predictions for the Turkish electricity sector with actual developments. We also assess the differences between model and actual outcome in terms of environmental sustainability indicators (i.e. greenhouse gas and pollutant emissions).

The remainder of the paper is organized as follows: Section 2 contains some general considerations regarding the adoption of electricity generating technologies. Section 3 introduces the literature and theoretical approaches considered, section 4 describes and discusses the proposed model formulation, and section 5 presents the empirical analysis and results from applying our model to the Turkish electricity-generating sector. Section 6 summarizes and concludes.

\section{Electricity system capacity (expansion) planning and the adoption of power generation technologies}

Because of the long lead times involved, capacity planning in the electricity supply industry has always been of paramount importance. Before market liberalization, such capacity planning was mainly undertaken to ensure that installed capacity plus net import capacities are able to meet electricity demand at all times. According to $\mathrm{Ku}$ (1995), power plant investment decisions are threefold: (a) what to build (choice and mix of technology); (b) how much to build (capacity); and (c) when to build (timing and sequencing). What to build is a matter of available technologies (and fuel resources), their performance characteristics, expected construction times and cost, expected operating lifetimes, expected fuel cost, and other factors. How much and when to build is a matter of demand projections, existing (over)capacity, the plant retirement schedule, financial constraints, and other factors. In the case of (partial) irreversibility of investment expenditures and uncertainty, how much and when to build is also affected by a firm's flexibility to postpone an investment and the related determination of the optimal investment timing as a function of the (real options) value of waiting.

In real life, capacity planning decisions also involve trade-offs between proven and new technologies, an evaluation of the costs and benefits of over- and under-capacity, and decisions on the postponement of investment decisions in anticipation of regulatory changes (Ku, 1995, p.51). Schedules for investments in the electricity generating capital stock may cover time periods of 4050 years, and are often strongly influenced by political considerations (e.g. use of domestic energy resources, supply security and diversification aspects, environmental protection).

Electricity supply capacity investments typically involve irreversible decisions with far-reaching consequences. These long-term policy implications can be captured using a computable general equilibrium model with sufficient technological detail in the electricity sector. While models using such a hybrid top-down bottom-up approach are superior for policy analysis (e.g. Kumbaroğlu and Madlener, 2003), they are less relevant for investment planning, as they neglect uncertainties with potentially essential impact on the investment decisions to be taken. Investment planning in liberalized electricity markets poses new modeling challenges due to additional uncertainties as a by-product of market restructuring (Dyner and Larsen, 2001; among others). These may be criti-

\footnotetext{
${ }^{3}$ Wien Automatic System Planning; a linear programming model operated by TEAŞ, which uses the forecasts of MAED to determine the least-cost electricity generation/capacity expansion plans.
} 
cal determinants of investors' behavior. Furthermore, capacity additions of technologies that feature modular characteristics can be made in smaller units (e.g. gas turbines, wind turbines, PV), contrary to conventional technologies (e.g. large hydro power projects), influencing the valuation of risk (e.g. Bar-Ilan and Strange, 1999; Murto, 2003b). Finally, technological risk and uncertainty can also play an important role in making the valuation of investment options with respect to electricity supply very difficult (e.g. Choi, 1994; Balcer and Lippman, 1984; Rosenberg, 1976).

\section{Literature review and theoretical approaches considered}

In this section we will provide a short literature review on research that is closely related to ours and also discuss elements that have been used in applied research on optimal capacity planning in the electricity supply industry under irreversibility and uncertainty.

An early work on optimal capacity choice in the electricity supply sector under uncertainty is that of Brown and Johnson (1969). They assume homogeneous production technologies (i.e. disregarding technological, operational and economic differences) and restrict uncertainty to the electricity demand function.

Levin, Tishler and Zahavi (1985) studied capacity expansion of electric power generation systems when input fuel prices are uncertain. They consider two different types of technologies (a peak and an off-peak unit) that meet power demand of a given target year and map the probability distribution of the installed capacity and the total cost for any distribution of fuel prices.

Kobila (1990), in a mathematically very rigorous manner, addresses the choice between hydro and thermal power generation in Norway under stochastic electricity demand. He expresses the cost of hydro power as an everlasting and irreversible capital investment, while for thermal power generation he considers the variable fuel costs (of natural gas) only. The focus of the paper is on the optimal timing for switching from thermal to hydro power in supplying a given electricity demand level at minimum cost.

Pindyck (1993) studies irreversible investment decisions by incorporating, on the one hand, uncertainties related to physical difficulties in completing a power plant project (technical uncertainty) and, on the other hand, uncertainties related to construction input cost and construction cost affected by government regulation changes. His empirical analysis focuses on decisions to start or continue investing in nuclear power plant projects in the U.S. during the early 1980s.

Chaton (1997) determines optimal investment in thermal power plants in a two-period model, given uncertainty in both input fuel prices and electricity demand. Her model explicitly takes the load duration curve into account for demand modeling. Recently, this model has been extended by Chaton and Doucet (2003) to three periods (to account for the option of investors to delay planned investments), to endogenize plant availability (as a function of intensity of use over time), and to explicitly account for electricity trading.

Epaulard and Gallon (2000), using real options theory, study the investment choice between nuclear and natural-gas-fired power plants and compare the outcome with traditional net present value (NPV) calculations.

Murto (2003b) provides a compilation of papers (doctoral thesis) on dynamic investment models under uncertainty with a main focus on energy markets. He covers several aspects of optimal capacity expansion modeling, including technological and revenue-related uncertainties, irreversible 
investment choices related to energy projects with different degrees of uncertainty, and the incorporation of game theoretic elements.

Keppo and $\mathrm{Lu}$ (2003) extend the theory of irreversible investment under uncertainty for the case of a large energy company, whose electricity production decision affects the price of electricity.

Finally, Moreira, Rocha and David (2004) study thermal power generation investments in Brazil by employing a stochastic dynamic programming approach and real options theory. They consider uncertainty in the load, the input fuel price, and other economic factors. The present paper adds to this literature.

\section{Model formulation and discussion}

\subsection{Load duration curve and merit order}

The demand for power is traditionally described by a load duration curve (LDC), i.e. by a graphical summary of demand levels with corresponding (non-chronological) time durations. In regulated markets, the LDC is typically used together with screening curves (in which, for comparing the generation costs of different technologies, annual revenue requirements are plotted as a function of capacity factors, $\mathrm{CF}$ ) to determine the optimal mix of generation technologies. This procedure, also referred to as the merit order approach, is no longer applicable in a competitive market environment because of uncertainty (e.g. regarding cost and demand). Still, the LDC provides a useful summary of a year's worth of hourly fluctuations in electricity demand. A discretized LDC (i.e. one that is segmented into vertical sections) is shown in Figure 1, which also illustrates the significance of some of the variables and parameters defined in the model that is developed and used in this paper. The LDC is further segmented into horizontal bands that represent technologies (denoted by the subscript $j$ ) allocated to meet certain load sections (bands).

The cost-based ranking of technologies in a merit order that may be employed for the optimal dispatching of power can be illustrated in Figure 1 as follows. The lowest-cost technology is in use during all periods (of durations $\theta_{1}+\theta_{2}+\theta_{3}+\theta_{4}$ in the example given), contributing $L_{1} \mathrm{kWh}$ of power, whereas peak demand (of duration $\theta_{1}$ ) is satisfied by the more flexible but also more expensive technologies (for low utilization rates) located at the top of the LDC, with contribution $L_{4}$. In the absence of competition, demand is inelastic, implying a fixed LDC. Therefore, the 'demand curve' $\left(D_{1}, \ldots, D_{4}\right)$ indicates revenue per unit time. It defines the screening curve. The screening curve then shows the $\mathrm{CF}$ at which a different technology becomes cheapest, and hence the CF in the LDC to schedule the optimal dispatching of the load (cf. Chaton and Doucet, 2003, Fig. 1). Anderson (1972) has reviewed early modeling studies employing this traditional technique to determine least-cost investments in electricity supply. Note that this technique assumes a stable world that ignores the role of price in the determination of demand. In our model, we will also assume demand for electricity to be price-inelastic. This can be justified by noting that the period studied is characterized by a monopoly which leaves only the curtailment of consumption as a reaction to a price increase (rather than switching to another supplier). Moreover, the monopoly concerned was not profit-maximizing, thus aiming at a value of provision where price elasticity is low, and where electricity rates (regulatory process) and output (disallowance to choose the profit-maximizing output level, as utilities must provide the electricity demanded at all times) both have an exogenous character. However, we explicitly take cost, price and demand uncertainty into account in our model. 


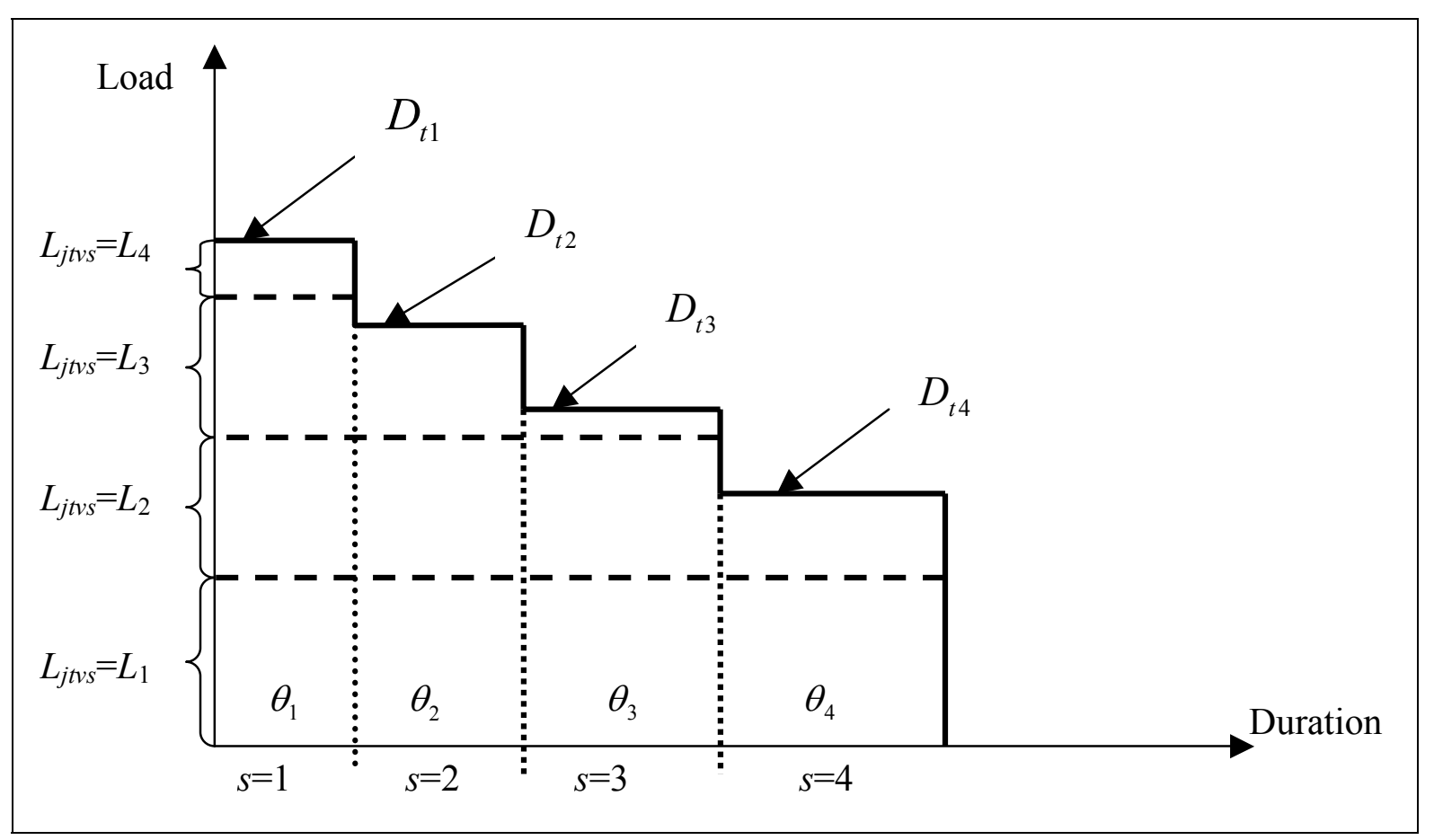

Fig. 1. A discretized load duration curve with horizontal bands.

\subsection{Objective function}

In spite of the non-profit nature of the Turkish electricity monopoly in the period 1970-2000 and in order to derive a benchmark, we use an objective function formulated in terms of expected net present value maximization. This is the expected discounted difference between revenues and fixed and variable costs that accrue from electricity production $E_{t}(N P V)$. Formally, this may be expressed as

$$
\begin{aligned}
E_{t}(N P V)= & \sum_{j=1}^{J} \sum_{\tau=t}^{T} \sum_{v=0}^{\tau} \sum_{s=1}^{S} E_{z_{\tau}}\left(P_{\tau}\right) \cdot L_{j \tau v s} \cdot \theta_{s} \\
& -\sum_{j=1}^{J} \sum_{v=1}^{T} f c_{j v} \cdot X_{j v}-\sum_{j=1}^{J} \sum_{\tau=t}^{T} \sum_{v=0}^{\tau} \sum_{s=1}^{S} E_{z_{\tau}}\left(v c_{j \tau v}\right) \cdot L_{j \tau v s} \cdot \theta_{s}
\end{aligned}
$$

where $f c_{j \nu}$ and $v c_{j} \tau_{\nu}$, respectively, stand for the discounted fixed costs (capital investment) ${ }^{4}$ and variable costs (operation and maintenance, O\&M) of technology $j$ with vintage $v$ in year $\tau$ (note that we assume a year-by-year evaluation in our model). Hence

$$
\begin{aligned}
& f c_{j v}=f c_{j}(1+r)^{-v} \quad \text { and } \\
& v c_{j \tau v}=v c_{j}(1+r)^{-\tau}(1+r)^{-v}
\end{aligned}
$$

\footnotetext{
${ }^{4}$ Investments are viewed as sunk costs, i.e. they cannot be recovered, say, if electricity prices fall and/or the investor wants to disinvest (e.g. dismantling of a dam). Similarly, the investment costs of existing plants are sunk and thus irrelevant for the present model. This irreversibility is a typical and reasonable assumption for electricity generation investments.
} 
where $r$ is the real discount rate. $E_{z \tau}\left(P_{\tau}\right)$ and $E_{z \tau}\left(v c_{j} \tau_{v}\right)$ in equation (1) represent the expected values of electricity price and variable costs, respectively, for different states of nature $z_{\tau}$. The installed capacity ${ }^{5}$ of technology $j$, vintage $v$, is represented by $X_{j p}$, and $L_{j} \tau_{v s}$ denotes the dispatched load of technology $j$, vintage $v$, operating in the sth section of the load duration curve in year $\tau$, the load duration in each section being $\theta_{s}$.

Timing of an irreversible investment under uncertainty matters. Hence if a company has the opportunity to postpone an investment, this option should be appropriately valued and included in today's investment decision. In dynamic programming the sequence of investment decisions is broken up into two parts, one that addresses the immediate choice and one that addresses all subsequent remaining decisions. Assume that when the company chooses the control variables $u_{t}$, representing its available choices at time $t$, it gets an immediate profit flow, $\pi_{t}\left(u_{t}\right)$. Expected optimal decisions after that will yield $E_{t}\left(N P V_{t+1}\right)$, sometimes referred to as the continuation value. Hence, the optimal investment timing problem can be specified as

$$
E_{t}(N P V)=\max _{u_{t}}\left\{\pi_{t}\left(u_{t}\right)+\frac{1}{1+\rho} E_{t}\left(N P V_{t+1}\right),\right\},
$$

which corresponds to the Bellman equation, or fundamental equation of optimality (e.g. Dixit and Pindyck, 1994, Ch. 4). Quite obviously, if a company invests at time $t$, it gets the expected present value of the revenues minus the cost. In contrast, if it waits and invests at time $(t+1)$, a real option that, if exercised, yields a higher net profit might arise. Then, it gets the continuation value $E_{t+1}(N P V)$, which has to be discounted by the factor $1 /(1+\rho)$ for being comparable at time $t$ with the immediate investment. The optimal choice is naturally the one that yields the larger outcome. For infinite planning horizons each decision leads to a problem that looks like the previous problem, and the model can be solved recursively. In case of a fixed finite time horizon, $T$, one can start the optimization from a termination payoff, and work backwards in solving the maximization problem. Such a dynamic decision framework allows to systematically compare the expected net present values from immediate investment and from waiting to invest. The ability to introduce and value the temporal flexibility in an irreversible investment decision represents the main distinction between real options and conventional decision analysis based on NPV.

The ability to delay an irreversible investment expenditure and invest at some later point in time, when a more profitable 'real' investment option can be realized with a certain probability, is incorporated into our model through the maximization of $E_{t}(N P V)$ over all time periods. That is, we specify our objective function as

$$
\text { Maximize } \sum_{t} E_{t}(N P V) /(1+\delta)^{t} \text {. }
$$

Hence the model determines the timing of investments endogenously such that the discounted total of expected net present values is maximized. This implies that there is an implicit incentive to wait and invest in a future period if it is (expected to be) more profitable, i.e. the model takes account of the value-of-waiting. This feature is in line with the real options idea, especially since uncertainties are explicitly taken into account in the dynamic decision-making process (see section 4.3). However, it should be noted that we do not decompose the problem and employ a multi-stage recursive computation, as suggested by the dynamic programming approach, but instead implement a classical optimization approach that maximizes the NPV of all options dynamically

\footnotetext{
${ }^{5}$ For simplicity, we assume that capacity is perfectly divisible.
} 
under a specified set of constraints (see section 4.4). Specifically, we solve the problem using MINOS, a reduced-gradient method with quasi-Newton approximations to the reduced Hessian (Murtagh and Saunders, 1980). It turns out that our modeling approach is satisfactory in terms of computational efficiency.

Closely related to the problem of waiting with an investment is that of choosing the optimal time to build (Majd and Pindyck 1987) and the often unavoidable discrepancy between, on the one hand, the time an investment decision is taken and costs start to occur and, on the other hand, the time revenues from an investment start to flow (e.g. Alvarez and Keppo, 2002; Bar-Ilan and Strange, 1996). We do not consider the latter aspect in the present application due to the unavailability of the necessary data.

\subsection{Modeling of uncertainty}

The uncertainties arising from input and output price fluctuations are considered by computing their expected values as a discrete stochastic autoregressive moving average process of orders $p$ and $q, \operatorname{ARMA}(p, q)$. Hence, we model the variation in $\left(r^{p} l^{p}\right)$ input fuel prices (the only O\&M costs considered) as

$$
v c_{j, \tau}=\alpha_{0}+\sum_{i=1}^{p} \alpha_{i} v c_{\tau-i}+\sum_{i=0}^{q} \beta_{i} \varepsilon_{\tau-i}
$$

where $\alpha_{0}$ and $\alpha_{i}$ are constants, with $-1<\alpha_{i}<1$, and $\varepsilon_{\tau_{-i}}$ is a normally distributed random variable with mean zero. The variation in the (real) average electricity price and of peak load capacity (see constraint no. 2 in the following section), respectively, is modeled analogously.

Obviously, NPV-maximizing optimal vintages are determined by the model, which is referred to as optimal stopping. The model formulation is completed with a set of demand and capacity constraints summarized in section 4.4.

\subsection{Constraints}

The following three constraints, together with non-negativity constraints for all variables except $N P V$, complete the model formulation.

Constraint No. 1: The available installed capacity must be sufficient to meet peak load demand almost always.

$$
\sum_{j=1}^{J} \sum_{v=0}^{\tau} a_{j v} X_{j v} \geq E_{z_{\tau}}\left(D_{\tau s}\right) \cdot(1+m) \quad s=1, \tau=1, \ldots, T
$$

where $a_{j v}$ is the availability factor for plant $j$ and vintage $v$, and $m$ denotes the reserve margin in percent.

Constraint No. 2: Total plant output must be sufficient to meet instantaneous power demand levels, on expectation.

\footnotetext{
${ }^{6}$ All prices, expressed in the Turkish energy statistics in U.S. Dollars, have been deflated by using the U.S. GDP deflator $(2000=1)$ published by the U.S. Department of Commerce, Bureau of Economic Analysis.
} 


$$
\sum_{j=1}^{J} \sum_{v=0}^{\tau} L_{j \tau v s} \geq E_{z_{\tau}}\left(D_{\tau s}\right) \quad s=1, \ldots, S \quad \tau=1, \ldots, T
$$

where the expected peak-load capacity requirement for each technology (hard coal, lignite, natural gas, oil, geothermal, and hydro), $L_{j \text { max }}$, is modeled as a stochastic process with an $\operatorname{ARMA}(p, q)$ model formulation, as already indicated above.

Constraint No. 3: Output from each plant cannot exceed available capacity.

$$
\begin{array}{ll}
\text { (a) } L_{j \tau v s} \leq a_{j v} X_{j v} & \forall j, \tau, s, v=0, \ldots ., t \\
\text { (b) } \sum_{s=1}^{S} L_{j \tau v s} \theta_{s} \leq b_{j} X_{j v} & v=0, \ldots, \tau \quad \tau=1, \ldots, T
\end{array}
$$

where $b_{j}$ is the load factor for technology $j$ (the average production of the plant divided by its maximum).

\section{Empirical analysis and model results}

To empirically illustrate and assess our theoretical modeling assumptions and results, we apply the model formulation presented in section 4 to the Turkish electricity supply sector, one of the most dynamically evolving in the world. To this end we first analyze the development of electricity supply and use in Turkey.

\subsection{Electricity demand and supply in Turkey $^{7}$}

Electricity supply considerations in Turkey have been strongly driven by a rapid growth on the demand side, and the historical dominance of hydro power and fossil-fuel-based thermal power generation on the supply side (IEA, 2001, Kaygusuz, 2002, Ediger and Kentel, 1999, among others; see also Figure 4). Until recently, the Turkish electricity sector was dominated by a stateowned vertically integrated utility. It was unbundled in 1993 into the Turkish Electricity Generation and Transmission Company (TEAŞ) and the Turkish Electricity Distribution Company (TEDASS). TEAŞ is responsible for the operation of all state-owned plants as well as transmission and imports and exports of electricity. In spite of a market opening process that was initiated as early as 1984, when foreign private investors were invited to play a role in the Turkish electricity supply industry $^{8}$, the major part of installed electricity generation capacity is still owned by TEASS. However, its share is gradually declining, and concessionaires, industrial auto-producers and others are gaining market shares. In 2001, TEAŞ has been further split into EÜAŞ (generation), TETAŞ (trading and contracting) and TEIASS (transmission). Currently, in a new wave of reform, further market opening and unbundling is under way, driven by the desire to introduce competition and

\footnotetext{
${ }^{7}$ This subsection is essentially based on IEA (2001), as well as Ediger (2003a) and references therein. If appropriate, additional references are provided.

${ }^{8}$ A new law in 1984 opened the way for private participation in the electricity sector, facilitating so-called BuildOperate-Transfer and Transfer-of-Operation-Rights contracts. Privatisation, however, could not follow by that time as electricity was being interpreted by the constitution as a public service. A constitutional amendment in 1999 made privatisation possible, and the regulatory framework to establish a competitive electricity market has been developed in late 2001.
} 
prepare for EU accession, and to meet certain requirements of IMF and World Bank support programs.

Electricity demand in Turkey has been growing at a remarkable average rate of $10.8 \%$ over the last 50 years, inducing annual investments in the generation, transmission and distribution infrastructure in the order of US\$ 4-5 billion. Installed generation capacity today is provided by some 350 power plants and is estimated to be around $36.3 \mathrm{GW}$ in 2003 (Table 1). While only some $7 \%$ of the villages had grid access in 1970, this percentage increased to $61 \%$ by 1982 and to $99.9 \%$ by 1999 (IEA 2001).

Table 1. Electricity balance of Turkey, 1950-2003

\begin{tabular}{lrrrrrrr}
\hline & 1950 & 1960 & 1970 & 1980 & 1990 & \multicolumn{1}{c}{2000} & \multicolumn{1}{c}{$2003^{*}$} \\
\hline Total installed capacity (MW) & 407.8 & 1272.4 & 2234.9 & 5118.7 & 16317.6 & 27264.1 & 36283.1 \\
Electricity generation (GWh) & 789.5 & 2815.1 & 8623.0 & 23275.4 & 57543.9 & 124921.6 & 139245.0 \\
Import surplus (GWh) & - & - & - & 1341.2 & 732.2 & 3354.0 & 3255.0 \\
Electricity consumption (GWh) & 789.5 & 2815.1 & 8623.0 & 24616.6 & 56811.7 & 128275.6 & 142500.0 \\
\hline
\end{tabular}

Data source: TEİAŞ (2002)

*Estimates

Additions to installed capacity have come in bursts, as Figure $2 \mathrm{a}$ illustrates. Figure $2 \mathrm{~b}$ shows the evolution of the energy sources and related technologies used in power generation, with hard coal almost entirely replaced first by petroleum and then by hydro power in the course of 40 years.

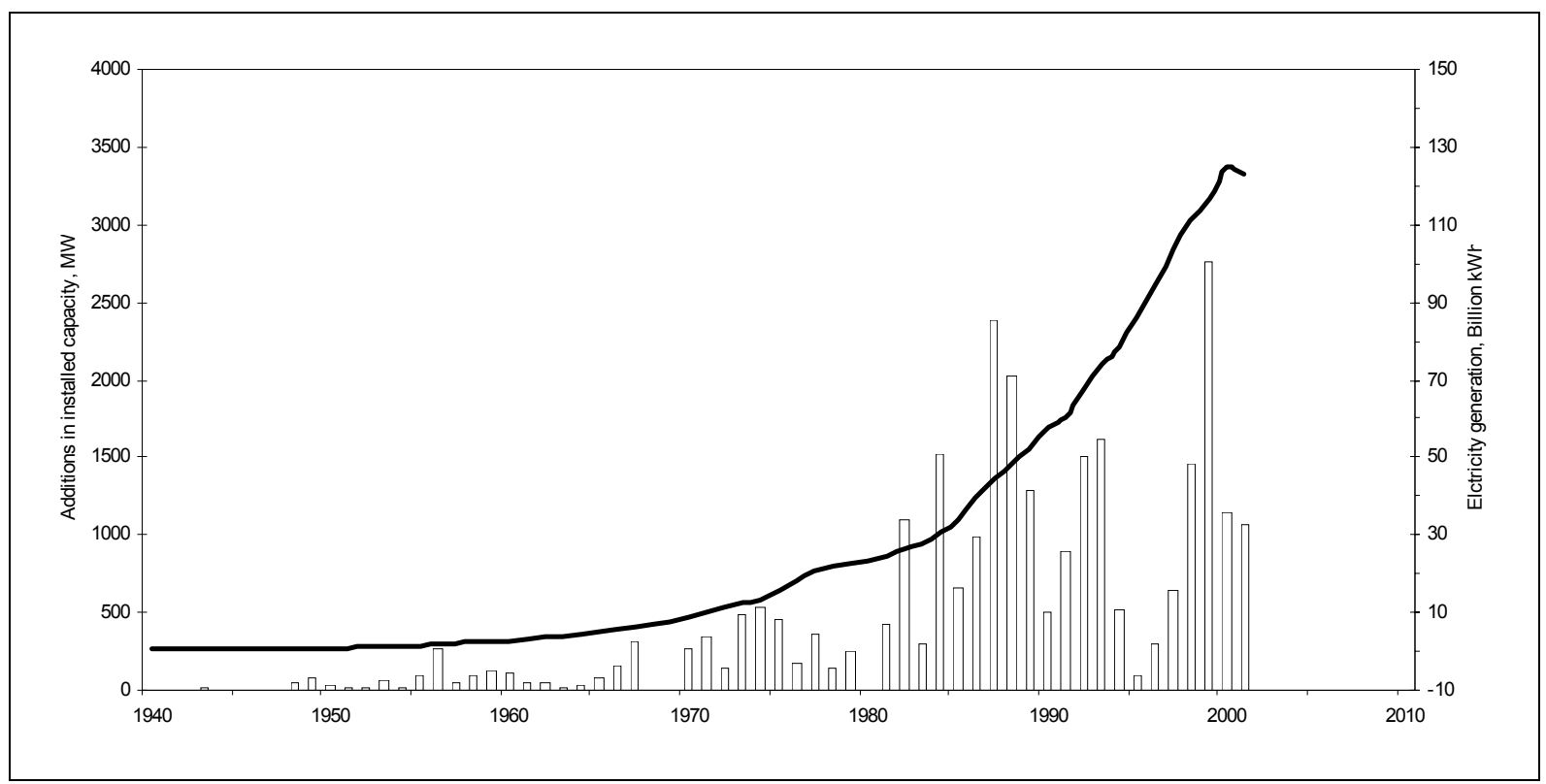

Fig. 2a. Additions in installed capacity (left scale) and power generation (right scale), 1940-2001

In the 1950s, the dominant fuel for power generation in Turkey was hard coal. Its share in total installed capacity declined gradually from $52.1 \%$ (212.6 MW) in 1950 to $27.4 \%$ (348.3 MW) in 1960. By that year, hydroelectric energy supply had reached a share in capacity of $32.4 \%$ (411.9 MW). 


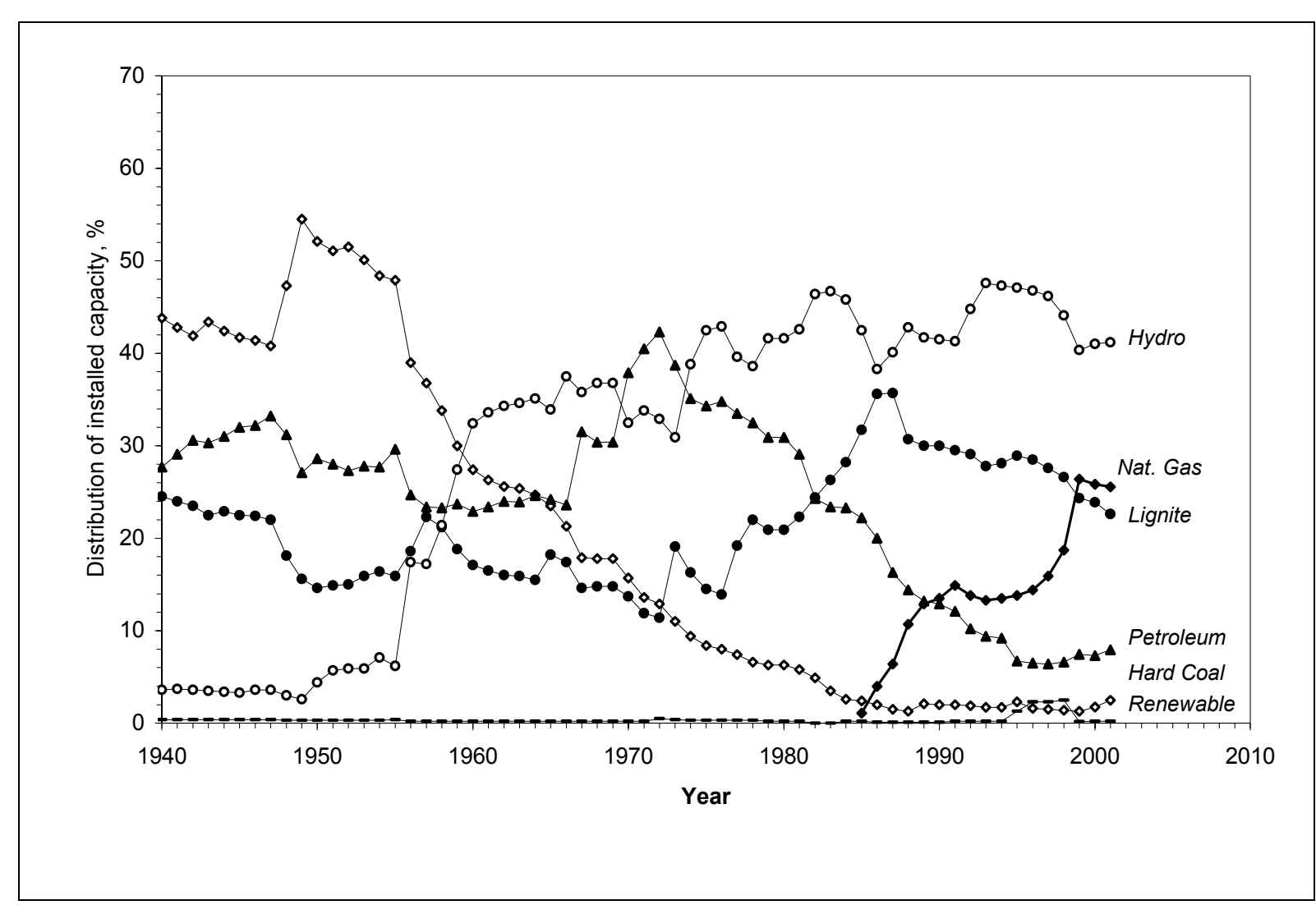

Fig. 2b. Shares of installed capacity, by energy source, 1940-2001 (modified after Ediger, 2003 bc).

Turkish electricity generation rests on hydro power and fossil-fueled thermal power generation. The rise of hydro power started with the evaluation of technically and economically feasible hydro power potentials. Turkey's first hydroelectric power plant came online in 1956 (567 MW). Total installed capacity rose from 3.1 GW in 1982 to $11.2 \mathrm{GW}$ in 2000. The remaining economic hydro power potential has been estimated to be about $20 \mathrm{GW}$ (equivalent to an estimated construction cost of some US $\$ 30 \mathrm{bn}$, spread across some 330 additional plants). Investment planning in hydro power plants in recent years has been largely influenced by the huge South-East Anatolia Project (GAP), which combines hydro power use and increased irrigation by utilizing the water from the lower reaches of the Euphrat and Tigris rivers. The largest two hydro power plants in Turkey are Karakaya (1800 MW) and Atatürk (2400 MW). The Karakaya and Atatürk plants are part of the GAP project, which upon completion will comprise an installed capacity of some $7.5 \mathrm{GW}$, equivalent to about $22 \%$ of the total estimated economic hydro power potential of Turkey.

Since the 1970s emphasis has been put on the development of domestic energy resources, especially on lignite and on hydro power but much less on other renewables (see Ediger and Kentel, 1999, and more recently Evrendelik and Ertekin, 2003, for useful assessments of the renewable energy potentials in Turkey). The share of (largely domestically produced) lignite in electricity production increased from $19.1 \%$ in 1973 to $24.4 \%$ in 1982, rose further to $35.7 \%$ in 1987 and then declined again to $24.4 \%$ in 1999 .

The rise of natural gas came in the 1970s, although its share remained very modest until the 1980s. The share of natural-gas-fired power plants rose from $1.1 \%$ in 1985 to $26.4 \%$ in 1999, and the capacity added was in the order of $5 \mathrm{GW}$. 
First privatization efforts were undertaken as early as in the 1950s, when construction of power plants were initiated at a larger scale, both by publicly-owned and private enterprises operating under state concession. More extensive privatization in the electricity sector was initiated in 1984 with the first energy privatization law 3096 (also known as the 'BOT law'), designed to enable private actors to build and operate electricity generation, transmission and distribution systems. Law 3096 essentially foresaw two different types of contracts: BOT (Build Operate Transfer) contracts for planned projects and TOOR (Transfer Of Operation Rights) contracts for existing facilities. ' A further step in private participation followed ten years later, in 1994, with the BOO (Build Operate Own) Law, through which the plant ownership could remain on the investors. Typically, under a BOO, BOT or TOOR contract, the state guarantees to buy a certain amount of the production at specified prices, so that investors can recover their fixed costs. Despite these privatization efforts, in 2000 some $75 \%$ of the installed capacity in the electricity sector were still owned by the government.

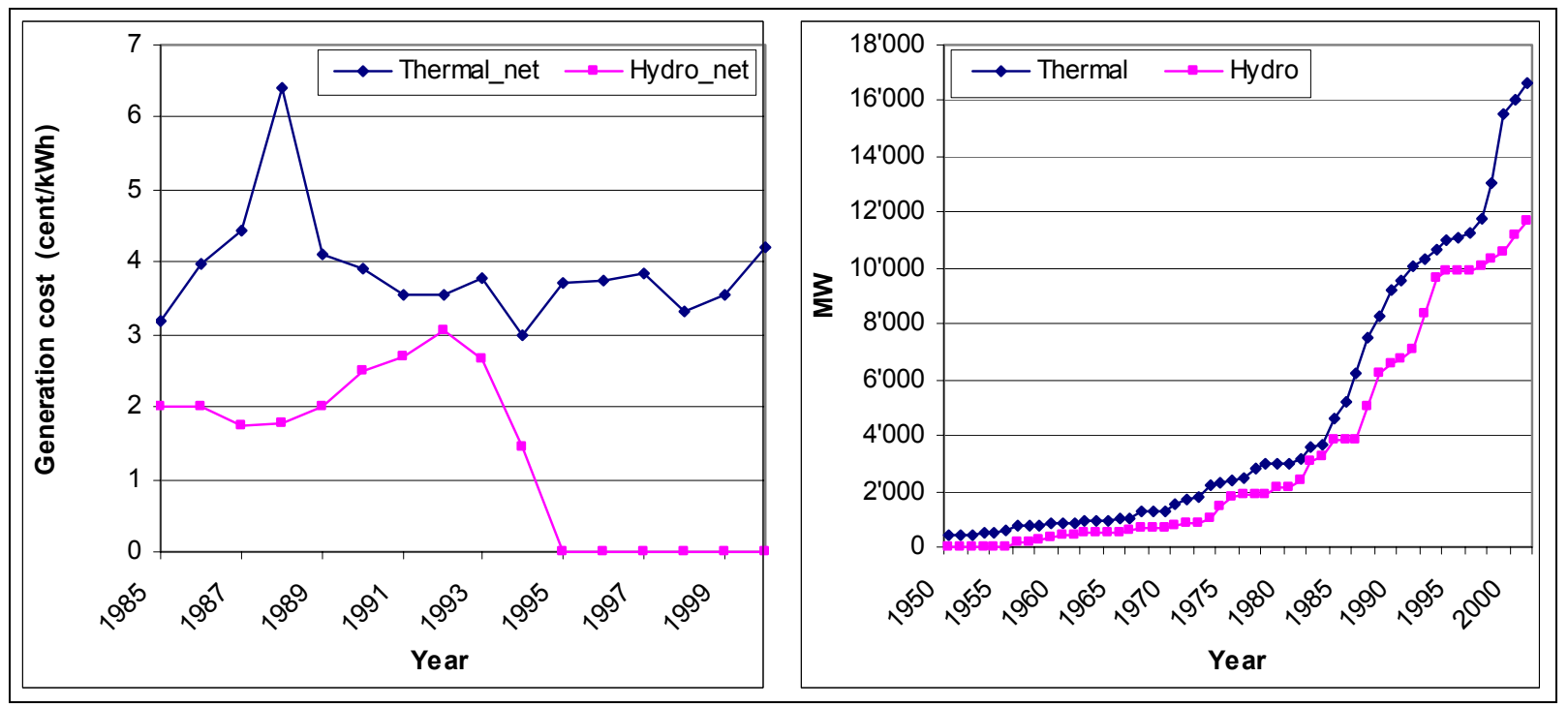

Fig. 3. Development of average thermal and hydro power generation cost (in real US-cents/kWh), 19852000 (left panel), and installed capacity (in MW), 1950-2001 (right panel).

The net electricity generation costs are presented in Figure 3 (left panel) for thermal and hydro power. The costs for hydro power generation exhibit a sudden fall after the Atatürk power plant became operational in 1993. This is because the Atatürk plant has started to produce electricity at rather low cost (i.e. at a net operating cost of 0.03 cent (US) per $\mathrm{kWh}$ ), replacing older and smaller hydro plants that were generating electricity at considerably higher cost (e.g. Keban at 6.2 cent $/ \mathrm{kWh}$, Botan at $10.9 \mathrm{cent} / \mathrm{kWh}$, Bozyazi at $8.9 \mathrm{cent} / \mathrm{kWh}$, and Denizli at $31.3 \mathrm{cent} / \mathrm{kWh}$ ). However, note that the generation cost for hydroelectric energy depicted in the left panel of Figure 3 are variable cost only. ${ }^{10}$ The development of installed thermal and hydro power generation capacities is plotted in the right panel of Figure 3. It shows the cumulative capacity effect of the structural changes reported in Figure 2.

\footnotetext{
${ }^{9}$ BOT: The plant is constructed by private investors who transfer it to the state after an operation period of about 20 years; TOOR: A lease-type agreement is made with private investors who renovate and operate an existing plant.

10 The data depicted in Figure 3 are based on TEAŞ (2001). The state-owned hydraulic works (DSI) is responsible for the development of hydro-electrical energy projects - after completion, the electricity generation company EÜAŞ starts to operate the hydro power plants, ignoring the construction costs specified by DSI in their cost accounting reports.
} 
Figure 4 illustrates the changing composition of total primary energy supply (TPES) in electricity generation for Turkey from 1973 to 1999, with predictions from 2000 to 2020. As can be seen it is expected that the share of hydro power will decrease, while the use of coal and nuclear power, and to a lesser extent natural gas, is expected to rise. New renewables are expected to emerge and start playing an increasingly significant role after 2010.

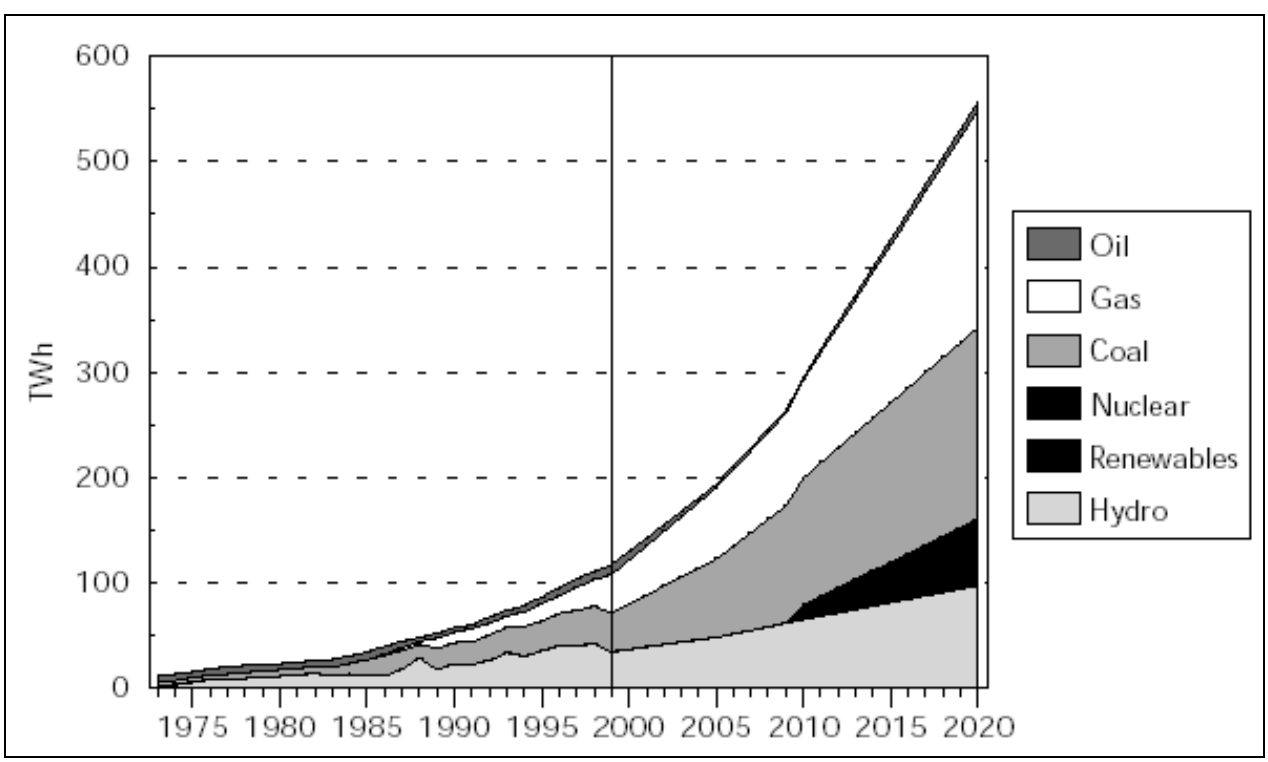

Fig. 4. Electricity generation by energy input source, 1973-1999, with projections until 2020.

Data source: IEA (2001, p.100).

Research on greenhouse gas emissions of the Turkish electricity supply industry (essentially $\mathrm{CO}_{2}$ ) is still rare. Most of the available energy-environment analyses (e.g. Kumbaroğlu, 1997; Plinke et al., 1990; Taşdemiroğlu, 1992) typically have focused on $\mathrm{SO}_{2}$ and $\mathrm{NO}_{\mathrm{x}}$ emissions, as these pollutants, until recently, had caused the most severe adverse environmental impacts in Turkey. Kaygusuz (2003) and Demirbaş (2003) are two recent studies exploring greenhouse gas emissions in Turkey.

Modeling studies exploring the economic impacts of environmental constraints in Turkey (e.g. Arrkan and Kumbaroğlu, 2002; Kumbaroğlu, 2003) typically do not explicitly capture the uncertainty inherent in input and output prices.

Utilization of renewable energy technologies except hydro electricity is still quite limited, amounting to only $0.1 \%$ of installed capacity in $2000 .{ }^{11}$ However, a considerable technical renewable energy potential exists in Turkey, amounting to some $495 \mathrm{TWh} /$ year in total according to recent studies undertaken by Evrendilek and Ertekin (2003). In particular, these authors estimate the potential for biomass energy at $196.7 \mathrm{TWh}$, for hydro power at $124 \mathrm{TWh}$, solar energy at 102.4 TWh, wind energy at $50 \mathrm{TWh}$, and geothermal energy at $22.4 \mathrm{TWh}$ per annum. Further discussions on the renewable energy potential and utilization in Turkey can be found in Ediger and Kentel (1999) and Kaygusuz and Sar1 (2003), among others.

\footnotetext{
11 The $0.1 \%$ renewable share includes geothermal and wind energy. Hydroelectric energy has a $41 \%$ share
} $(11175 \mathrm{MW})$ in the total installed capacity for the year 2000. 


\subsection{Model results}

In the empirical model application we explore investment decisions in electric generation capacity for the period 1970-2000, differentiating between various types of thermal power plants (i.e. fired by hard coal, lignite, natural gas, and oil) and hydro and geothermal power technologies of different vintages.

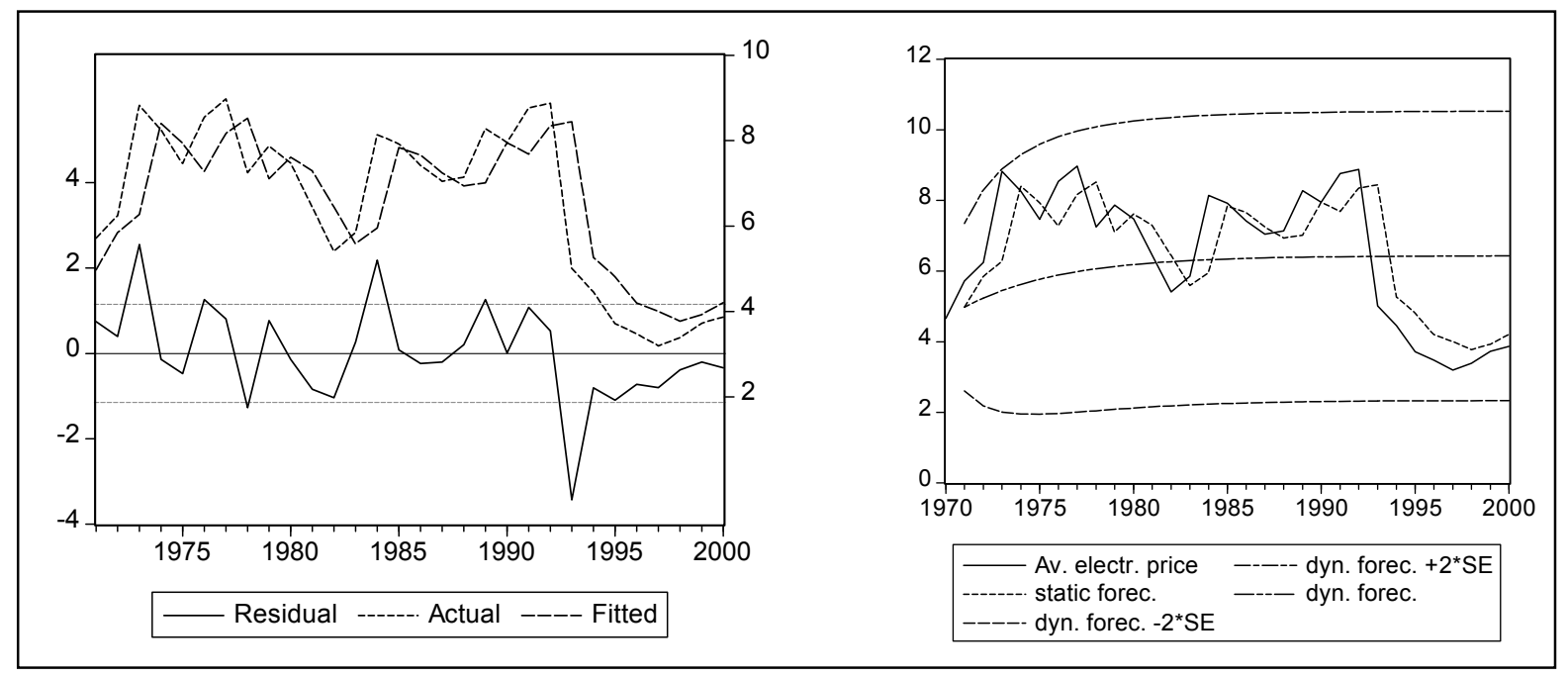

Fig. 5. Average electricity price development (real, in US-cent $/ \mathrm{kWh}$ ). Actual, fitted and residuals (left panel), and comparison between actuals and static 1-step-ahead and dynamic multi-step-ahead within-sample forecasts (right panel), 1970-2000.

As a first step we have estimated the parameters of the stochastic processes introduced in section 4.3 for electricity price, variable cost, and peak load demand. ${ }^{12}$ Particularly, for the exposition here we assume that the variables considered are all stationary ${ }^{13}$, and estimate various finite order $\operatorname{ARMA}(p, q)$ model specifications with $p$ and $q$ equal to 0,1 , and 2 . Of the altogether eight different models for each stochastic variable we have chosen the models which performed best in terms of parsimony and goodness of fit (Box-Jenkins approach), but also their forecasting ability. The model estimation and within-sample forecasting results obtained are shown in Table A.1 and Table A.2 in the Appendix. Figure 5 shows the fitted and forecasted values for the average electricity price variable as an illustration. ${ }^{14}$

\footnotetext{
${ }^{12}$ We have used the econometrics software package EViews 4.1 of Quantitative Micro Software, Irvine, CA.

${ }^{13}$ We acknowledge the need for unit root (UR) testing in order to assess the stationarity properties of the variables studied. At the same time, however, it is quite clear that given the small number of available observations, these tests have a severe lack of power. As Table A.3 shows, the UR tests revealed that the peak-load capacity (PLC) for geothermal power and natural gas (barely) are integrated of order zero, $I(0)$, as the null hypothesis of a unit root is rejected, while from the tests we conclude that fuel oil, hard coal, lignite (barely), and hydro PLC seem to be $I(1)$. With respect to unit generation cost (UGC), those of geothermal power and natural gas (note that the ADF and PP tests yield contradictory results) appear as $I(0)$ variables, while those of fuel oil, hard coal, lignite (barely), and hydro power UGC seem to be $I(1)$. Finally, for the average price of electricity, we find some (weak) evidence that it could be $I(1)$ as well. Given the very small sample sizes, however, we must caution against too much reliance on these results, as it is well known that it can be very difficult to distinguish between trend-stationary and unit root processes in finite samples (e.g. Campbell and Perron, 1991, p.157). For this reason, and because of a lack of space, we have refrained from pursuing any cointegration analysis here.
}

${ }^{14}$ Detailed results can be obtained from the authors upon request. 
The optimal investment model for power generation technology adoption in the electricity supply industry has been programmed in GAMS and results have been obtained with the solver MINOS. Load factors, annual durations and other reference parameters required for calibration are essentially based on TEAȘ (2001). ${ }^{15}$

The results yield technology selections that differ significantly from the actual choices made by policy-makers and/or investors. This can be gleaned from Figure 6, which presents the percentage deviation between model-determined and actual total installed capacity levels for thermal and hydro power. As opposed to actual investment expenditures, the NPV-maximizing behavior of the model prefers to allocate more resources for the construction of hydro power plants than for thermal power plants in the 1970s and early 1980s, but predicts the take-up of installation of large thermal power plants thereafter. Investments in hydro power rise in the 1990s and the modeldetermined and actual installed capacities become almost equal in 2000, but the share of hydro power in total electric energy supply declines slightly due to the dominating increase in investments into thermal power generating technologies.

A closer look into the composition of thermal power, especially the development of natural-gasand lignite-fired technologies, provides interesting findings. In contrast to the recent development with huge investments into natural-gas-fired technologies, the model prefers to utilize lignite-fired power generation technologies in significantly higher amounts, as illustrated in Figure 7. Hence, model-derived choices deviate from real-life ones in that the oil\&gas/solid fuels ratio becomes much lower in the case of NPV maximization. It should be underlined that a possible reason for this difference in preference is uncertainty. Natural gas is an imported energy source for Turkey, whereas lignites are domestic. Limited foreign exchange availability and economic instability, from time to time, lead to considerable fluctuations in natural gas prices. Hence the model suggests investment in domestic fuel-fired technology whose operation costs are more stable.

Model-based and actual investments in hydroelectric power plants are quite close in the year 2000 (model-based investments accumulate to an installed capacity level that exceeds the actual capacity level by $6 \%$ ), although there are some deviations in the timing of capacity additions. Some $97.3 \%$ of the total actual hydropower capacity in the year 2000 is based on storage plants (with a dam), $2.3 \%$ on run-of-river plants, and $0.4 \%$ on natural storage plants (without a dam).

The actual investment behavior of decision-makers in the electricity generation sector in recent years, i.e. to prefer natural-gas-fired power plants over coal-fired plants, has been more environmentally friendly than the NPV-maximizing investment decisions predicted by the model, as the development of $\mathrm{CO} 2, \mathrm{SO} 2, \mathrm{NOx}$ and particulate emissions in Figure 8 shows. It seems that, although Turkey has not signed the Kyoto Protocol on Climate Change yet, she has chosen an ecologically more sustainable path with less greenhouse gas emission that would have been cho-

${ }^{15}$ Essential base case assumptions are as follows:

- The load duration curve is segmented into 4 sections (vertical bands) and 6 horizontal bands, accounting for hard-coal-fired, lignite-fired, natural-gas-fired, oil-fired, geothermal and hydro power generation technologies.

- The maximum plant size (electric capacity) that can be constructed per year is $1500 \mathrm{MW}$ for any technology.

- Natural gas and geothermal have been restricted such that they cannot be utilized before 1985 and 1984, respectively, when the necessary infrastructure became available.

- The deviation of aggregate total annual demand from actual values is subject to a tolerance level of $+/-20 \%$.

- Discount rate $=8 \%$, reserve margin $=10 \%$, availability factor $=90 \%$ (uniform for all technologies).

- $\mathrm{CO}_{2}$ emission factors are taken as $96.1 \mathrm{~kg} / \mathrm{GJ}$ for hard-coal-, $108.4 \mathrm{~kg} / \mathrm{GJ}$ for lignite-, $50.92 \mathrm{~kg} / \mathrm{GJ}$ for naturalgas-fired technologies and $73.74 \mathrm{~kg} / \mathrm{GJ}$ for oil-fired technologies (factors based on TEK 1994). 
sen on a net present value maximization criterion alone. Besides environmental concerns, strategic considerations, political and societal priorities, and long-term international agreements, which are not incorporated in the present model, may be responsible for this deviation.

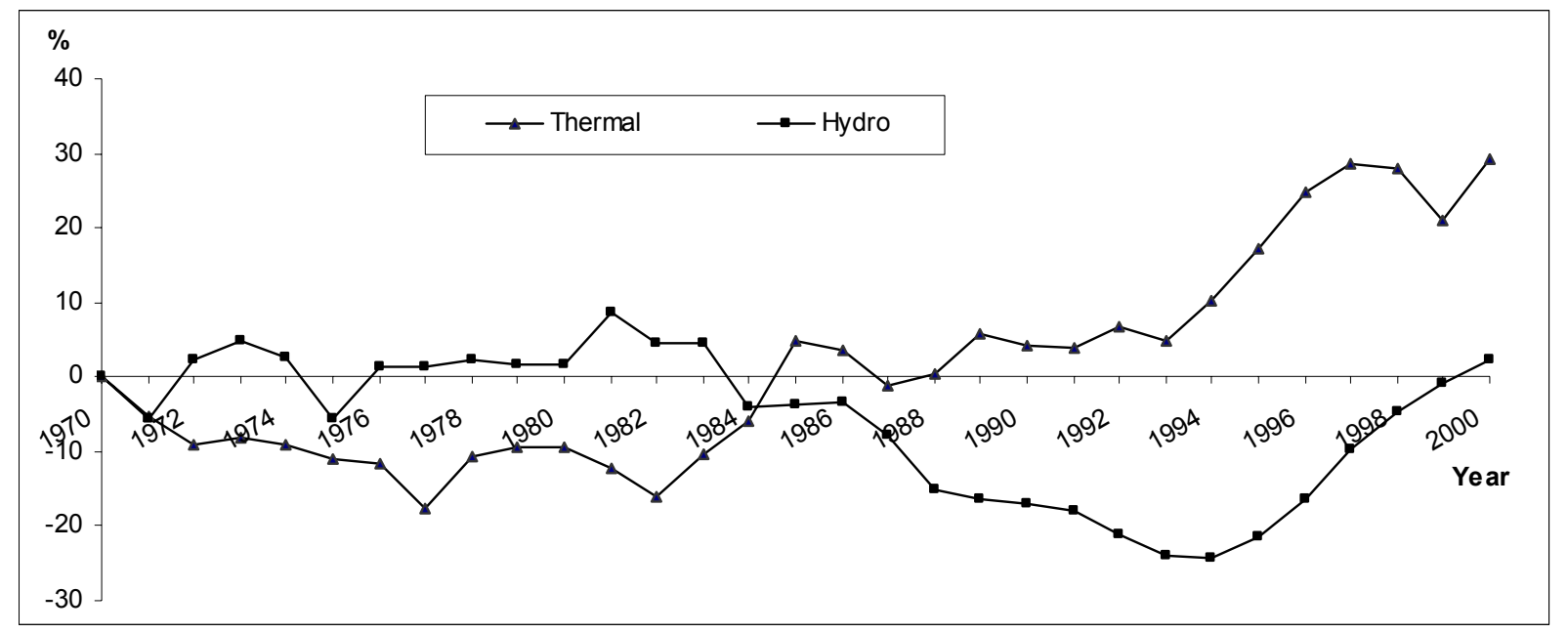

Fig. 6. Percentage deviation of NPV-maximizing investments in hydro- and thermal- based power generation technologies from actual ones, 1970-2000.

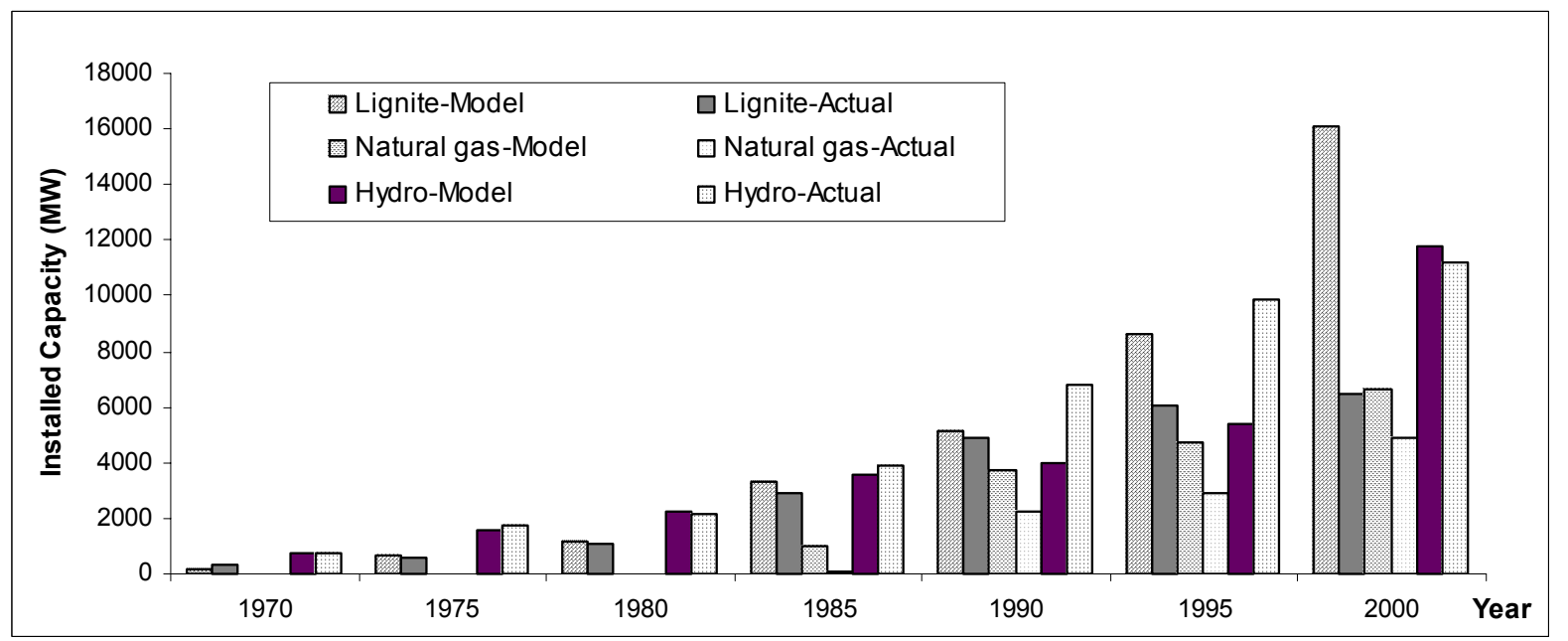

Fig. 7. Installed capacities: hydro power, natural-gas- and lignite-fuelled technologies, 1970-2000.

Environmental concerns have actually been a rather dominant driver. Especially in the early 1980s, winter months in major Turkish cities, esp. in Istanbul and Ankara, were characterized by heavy air pollution (see also IEA, 2001, Ch. 4). This certainly was a main motivation for policymakers to substitute natural gas as a relatively clean fuel for low-quality and high-sulfur domestic coal (lignite) used in heating systems and electricity generation. ${ }^{16}$ With the help of booming investments in gas-fired power generation technologies, Turkey has managed to effectively slow

\footnotetext{
${ }^{16}$ In 1998, when coal and lignite still accounted for about $32 \%$ of total electricity production in Turkey, the electricity sector emitted some 1.29 million tonnes of $\mathrm{SO}_{2}, 0.17$ million tonnes of $\mathrm{NO}_{\mathrm{x}}$, and 0.14 million tonnes of particulate matter (IEA, 2001, p.36). Electricity demand has been projected to increase by $250 \%$ by 2012, requiring some $41 \mathrm{GW}$ of new generation capacity. Assuming that about a fifth of the additional capacity needed would be coalfired, this resulted in a doubling of the coal-fired capacity (ibid.). The additional $\mathrm{SO}_{\mathrm{x}}, \mathrm{NO}_{\mathrm{x}}$ and particulate emissions released would severely add to the emission problems predicted for automotive fuel use in transport.
} 
down growth in pollutant emissions. However, this path has at the same time significantly raised the dependence on imports of a country, which has only very limited foreign exchange and relies on heavy foreign exchange inflows to finance her outstanding external debt (which has reached some US\$ 114 bn or about $78 \%$ of GDP in 2001; e.g. Orhangazi, 2002). Note that the NPVmaximization as formulated in sections 4.2 and 4.3 does not take these macroeconomic uncertainties into account, though.
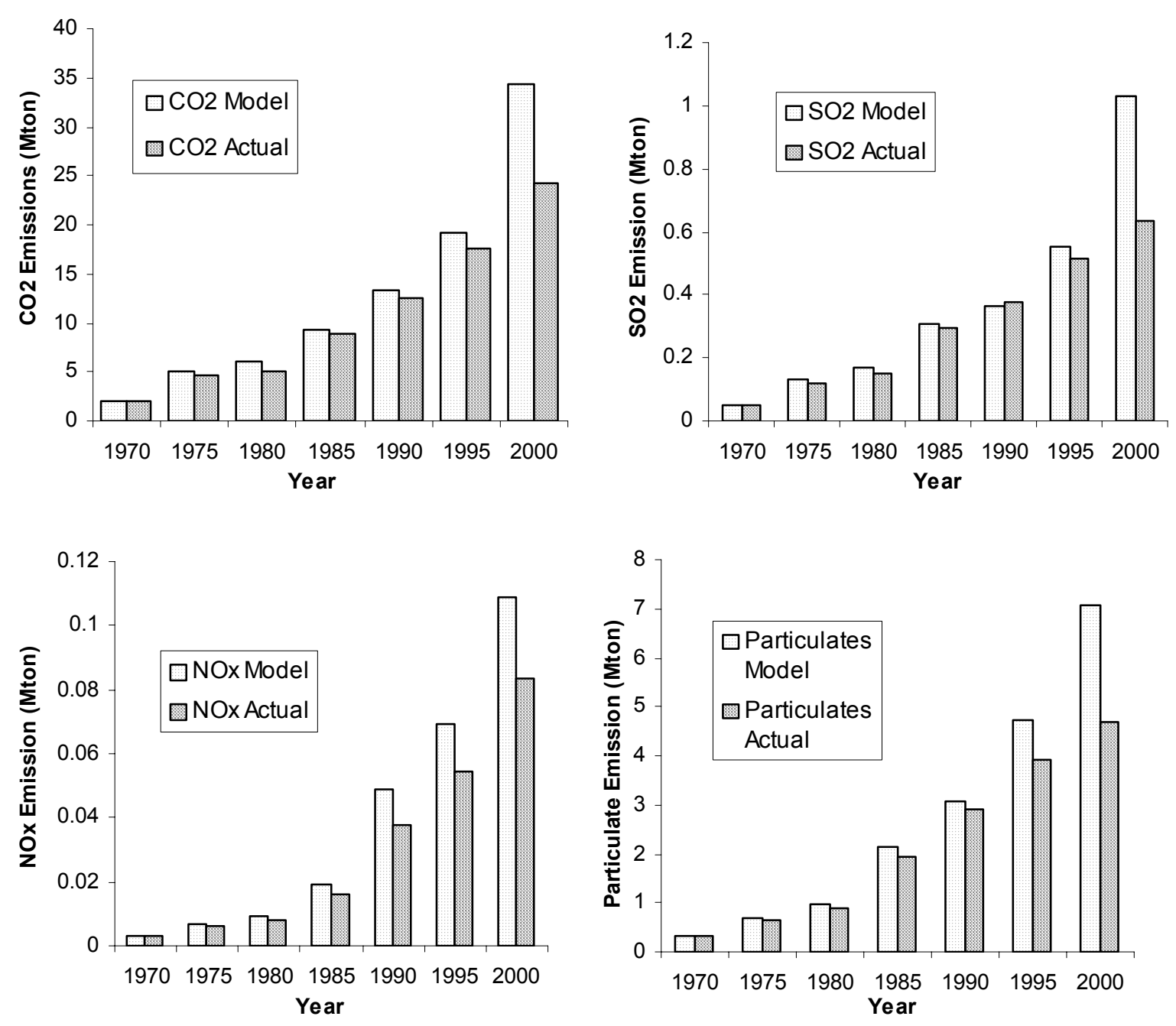

Fig. 8. NPV-maximizing and actual pollutant emissions, 1970-2000.

\subsection{Emission restrictions}

Substitution of hard coal and even more so lignite may have been a consequence of restrictions on emissions introduced during the 1980s. In order to explore this impact on electricity supply investment behavior, we have imposed the actual $\mathrm{CO}_{2}, \mathrm{SO}_{2}$ and $\mathrm{NO}_{\mathrm{x}}$ emission paths as upper bounds (with a $20 \%$ tolerance level) on the model solution. The three restrictions have similar effects, therefore only the results for $\mathrm{SO}_{2}$ (which has been the main source of air pollution in Turkey during the 1980s) are reported in Figure 9. The emission restriction scenario is shown in 
comparison with the reference run (BAU - Business-As-Usual scenario) as the percentage deviation from actual investments.

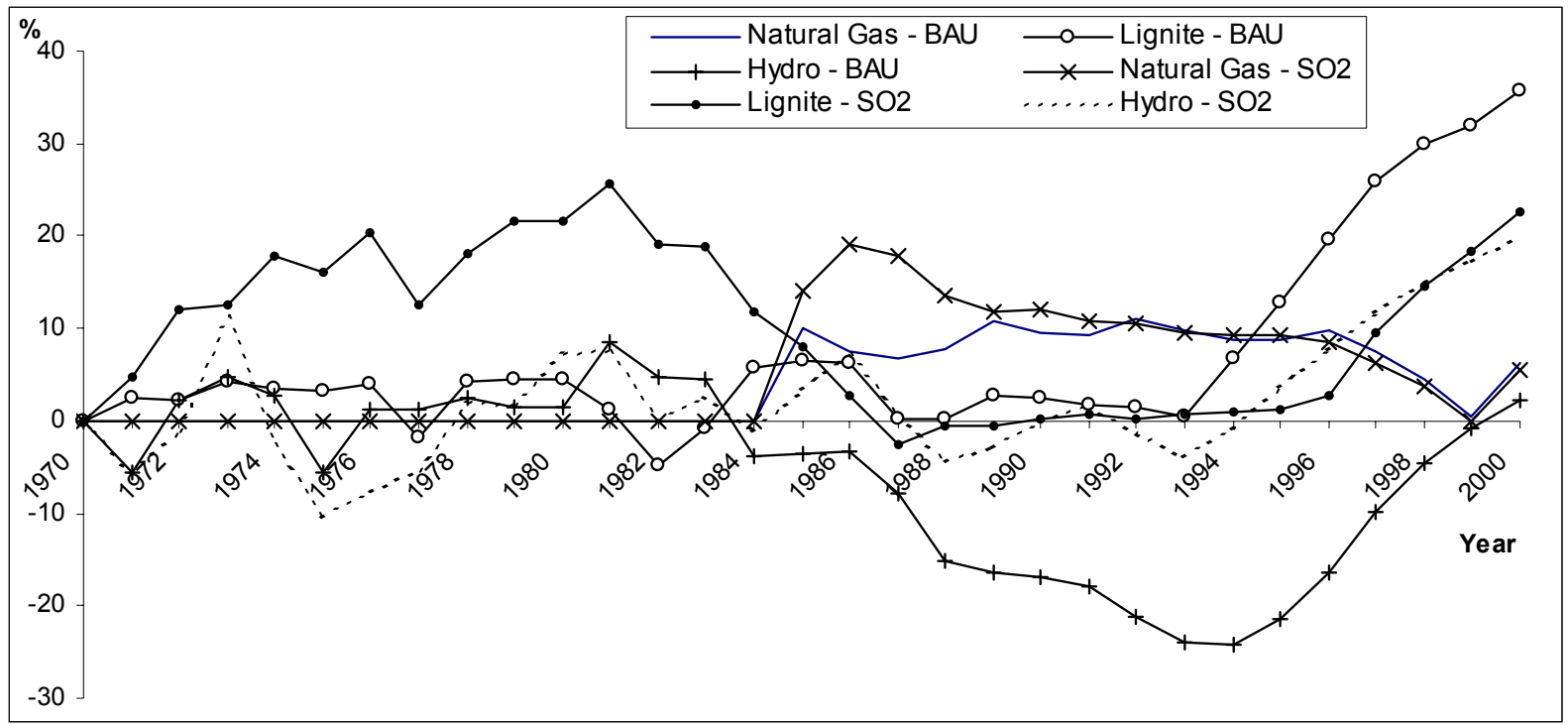

Fig. 9. Percentage deviation of NPV-maximizing investments (hydro, natural-gas- and lignite-fired technologies) from actual ones: BAU and $\mathrm{SO}_{2}$ Emission scenarios, 1970-2000.

Expectedly, restrictions on emission do reduce predicted investment in lignite-fired power generation technology, especially after 1994, bringing it down to a level close to the actual investment (Figure 9). To substitute for coal-fired technology, the model does not shift to invest in additional natural-gas-fired technology, but instead to utilize more hydro power. Accelerated investment in hydropower starts in the 1980s. The oil\&gas/solid fuels ratio of the restriction scenario becomes quite close to its actual value. Overall, these findings support the argument that environmental concerns have been a main motivation in preferring natural gas instead of domestic lignites. Given those environmental restrictions, decision-makers' investment behavior has been close to an NPV-maximizing path, except for some minor fluctuations (which can be explained by the model's failure to cover various socio-political concerns).

\section{Summary and conclusions}

In this paper we have applied a dynamic technology adoption model for the evaluation of irreversible investment options for electricity generating technologies, taking into account uncertainty, and vintage-specific life-cycle capital and operation costs. The consequences of electricity conversion technology choices for environmental sustainability have been a particular focus of our investigation.

In the case of Turkey, we find that historical investments strongly diverge from the prediction of the model, indicating that the actual choices are far off from what a net present value-based optimization model would suggest. In particular, there is an accelerated adoption of natural-gasfired technologies in reality that limits the increase in pollutant emissions, which would otherwise occur from the utilization of domestic fossil fuel sources. Indeed, according to the model investments in lignite-fired technologies should dominate in view of the lower volatility in lignite prices. Conversely, high volatility of natural gas prices (in domestic currency), essentially due to Turkey's 
economic instability and limited foreign exchange availability, reduces the attractiveness of technologies using this imported fuel.

The explicit inclusion of macroeconomic uncertainty, expected technological change and learning, regulatory change, capital depreciation, and construction lead times into the formulation of the model are promising avenues for further improvement and testing.

\section{Acknowledgements}

The authors gratefully acknowledge helpful comments received from Ilhan Or, Yves Smeers, and several other participants at the EcoMod 2003 and EURO/INFORMS 2003 conferences in Istanbul, July 2003, as well as from Peter Zweifel, Socioeconomic Institute, University of Zurich. Any remaining errors and misconceptions are of course our own. 


\section{References}

Alvarez, L.H.R., J. Keppo, 2002. The impact of delivery lags on irreversible investment under uncertainty, European Journal of Operational Research 136(1), 173-180.

Anderson, D., 1972. Models for Determining Least-Cost Investments in Electricity Supply, The Bell Journal of Economics and Management Science 3(1), 267-299.

Arrkan, Y., Kumbaroğlu, G., 2001. Endogenising Emission Taxes; A General Equilibrium Type Optimisation Model Applied for Turkey, Energy Policy 29(12), 1045-1056.

Arrkan, Y., Kumbaroğlu, G., 2000. Geçmişten günümüze enerji modelleri (Energy models from past to the future; in Turkish), Proceedings of the $8^{\text {th }}$ Turkish Energy Congress: Energy and Technology for Sustainable Development in the $21^{\text {st }}$ Century, WEC Turkish National Committee (May): 9-20.

Balcer, Y., S.A. Lippman, 1984. Technological expectations and adoption of improved technology, Journal of Economic Theory 34, 292-318.

Bar-Ilan, A., W.C. Strange, 1996. Investment lags, American Economic Review 86(3), 610-622.

Bar-Ilan, A., W. C. Strange, 1999. The Timing and Intensity of Investment, Journal of Macroeconomics 21(1), 57-77.

Benavides, J., 1995. Optimal pricing and investment in electric power generation in the context of uncertainty, PhD dissertation, College of Earth and Mineral Sciences, The Pennsylvania State University, University Park/PA.

Brown, G.M., Johnson, B., 1969. Public utility pricing and output under risk, American Economic Review 59(3), 119-128.

Campbell, J.Y., Perron, P., 1991. Pitfalls and opportunities: what macroeconomists should know about unit roots. In Blanchard, O.J. and Fischer, S. (eds.), NBER Economics Annual 1991, MIT Press, Cambridge/MA.

Chaton, C., 1997. Fuel price and demand uncertainties and investment in an electricity model: A twoperiod model, Journal of Energy and Development 23(1), 29-58.

Chaton, C., Doucet, J.A., 2003. Uncertainty and Investment in Electricity Generation with an Application to the Case of Hydro-Québec, Annals of Operations Research 120, 59-80.

Choi, J.P., 1994. Irreversible choice of uncertain technologies with network externalities, RAND Journal of Economics 25(3), 382-401.

Demirbaş, A., 2003. Energy and environmental issues relating to greenhouse gas emissions in Turkey, Energy Conversion and Management 44(1), 203-213.

Dixit, A.K., Pindyck, R.S., 1994. Investment under Uncertainty, Princeton: Princeton University Press.

Dyner, I., Larsen, E.R., 2001. From Planning to Strategy in the Electricity Industry, Energy Policy 29(13), $1145-1153$.

Ediger, V.Ş., 2003a. Development of the Power Generating Capacity of Turkey, unpublished mimeo. 
Ediger, V.Ş., 2003b. Elektrik sektöründeki tarihsel yakıt rekabetinin sistem dinamikleri-1 (System dynamics of historical fuel competition in the electricity sector-1), PetroGas 36(January), 60-64.

Ediger, V.Ş., 2003c. Elektrik sektöründeki tarihsel yakıt rekabetinin sistem dinamikleri-2 (System dynamics of historical fuel competition in the electricity sector-2), PetroGas 37(March), 62-67.-

Ediger, V.S., Kentel, E. 1999. Renewable energy potential as an alternative to fossil fuels in Turkey, Energy Conversion and Management 40, 743-755.

Ediger, V.S., Tatlıdil, H., 2002. Forecasting the primary energy demand in Turkey and analysis of cyclic patterns, Energy Conversion and Management 43(4), 473-487.

Epaulard, A.,Gallon, S., 2000. The Prospects of Nuclear Power in Europe's Deregulated Energy Markets Using Real Option Theory to Assess Nuclear Investment Value, Proceedings of the 2000 European Conference of the International Association for Energy Economics (IAEE) "Towards an Integrated European Energy Market", Bergen/Norway, 31 August - 2 September 2000

Evrendilek, F., Ertekin, C., 2003. Assessing the potential of renewable energy sources in Turkey, Renewable Energy 28(15), 2303-2315.

Henry, C., 1974. Option Values in the Economics of Irreplacable Assets, Review of Economic Studies 41(January), 89-104.

IEA, 2001. Energy Policy of IEA Countries. Turkey 2001 Review, Paris: OECD/IEA.

Karatzas, I., S. Shreve, 1991. Brownian Motion and Stochastic Calculus, Berlin/New York/London: Springer Verlag.

Kaygusuz, K., 2002. Sustainable development of hydropower and biomass energy in Turkey, Energy Conversion and Management 43(8), 1099-1120.

Kaygusuz, K., 2003. Energy policy and climate change in Turkey, Energy Conversion and Management 44(10), 1671-1688.

Kaygusuz, K.,Sar1, A., 2003. Renewable Energy Potential and Utilization in Turkey, Energy Conversion and Management 44(3), 459-478.

Keppo, J. and H. Lu, 2003. Real options and a large producer: the case of electricity markets, Energy Economics 25(5), 459-472.

Kobila, T.Ø., 1990. The choice between hydro and thermal power generation under uncertainty, in: O. Olsen and J. Vislie (eds.), Recent modelling approaches in applied energy economics, International Studies in Economic Modelling, New York: Routledge, Chapman and Hall.

Kobila, T., 1993. An application of reflected diffusions to the problem of choosing between hydro and thermal power generation, Stochastic Processes and their Applications 44(1), 117-139.

Ku, A., 1995. Modelling Uncertainty in Electricity Capacity Planning, PhD thesis, London: London Business School, February.

Kumbaroğlu, G.S., 1997. A model for long-term global air quality and development of efficient control strategies in Turkey, European Journal of Operations Research 102, 380-392.

Kumbaroğlu, G.S., 2003. Environmental Taxation and Economic Effects: A Computable General Equilibrium Analysis for Turkey, Journal of Policy Modeling 25(8), 795-810. 
Kumbaroğlu, G., R. Madlener, 2003. Energy and Climate Policy Analysis with the Hybrid Bottom-Up Computable General Equilibrium Model SCREEN: The Case of the Swiss $\mathrm{CO}_{2}$ Act, Annals of Operations Research 121(1-4), 181-203.

Laughton, D.G., Sagi, J.S., Samis, M.R., 2000. Modern Asset Pricing and Project Evaluation in the Energy Industry (condensed version), The Journal of Energy Literature 6(1), 3-46.

Levin, N., Tishler, A., Zahavi, J., 1985. Capacity expansion of power generation systems with uncertainty in the prices of primary energy sources, Management Science 31(2), 175-187.

Majd, S., R.S. Pindyck, 1987. Time to Build, Option Value, and Investment Decisions, Journal of Financial Economics 18(March), 7-27.

Moreira, A., Rocha, K., David, P., 2004. Thermopower generation investment in Brazil - economic conditions, Energy Policy 32(1), 91-100.

Murtagh, B.A., Saunders, M.A., 1980. MINOS/Augmented User's Manual, Stanford University Dept. of Operations Research, Stanford, California, USA.

Murto, P., 2003a. Timing of investment under technological and revenue related uncertainties, Systems Analysis Laboratory Research Report E11, Helsinki University of Technology (= part of Murto 2003b).

Murto, P., 2003b. On Investment, Uncertainty, and Strategic Interaction with Applications in Energy Markets, PhD Dissertation, Helsinki University of Technology, Systems Analysis Laboratory, April.

Orhangazi, Ö. (2002). Turkey: bankruptcy of neoliberal policies and the possibility of alternatives, Review of Radical Political Economics 34(3), 335-341.

Pindyck, R.S., 1993. Investments of Uncertain Costs, Journal of Financial Economics 34(1)(August), 53-76.

Plinke, E., Haasis, H.-D., Rentz, O., Sivrioğlu, M., 1990. Analysis of energy and environmental problems in Turkey by using a decision support model, $A M B I O$ 19(2), 75-81.

Rose, N.L., Joskow, P.L., 1990. The diffusion of new technologies: evidence from the electric utility industry, Rand Journal of Economics 21(3), 354-373.

Rosenberg, N., 1976. Perspectives on Technology, Cambridge: Cambridge University Press.

Sarkar, J., 1998. Technological diffusion: alternative theories and historical evidence, Journal of Economic Surveys 12(2), 131-176.

Taşdemiroğlu, E., 1992. Air pollutant emissions due to energy utilization in Turkey, Energy 17(1), 95-97.

TEAŞ, 2001. Türkiye Elektrik Üretim-İletim A.Ş. 2000 Yllı İstatistikleri (Turkish Electricity GenerationTransmission Co. Year 2000 Statistics), Report No.: APK-379.

TEİAŞ, 2002. Türkiye Elektrik İletim A.Ş. 2001 İşletme Faaliyetleri Raporu (Turkish Electricity Transmission Co. 2001 Annual Report), Report No. 475.

Thirtle, C.G., Ruttan, V.W., 1987. The Role of Demand and Supply in the Generation and Diffusion of Technical Change, Harwood Academic Publishers, Chur/London/Paris/New York. 


\section{Appendix}

Table A.1. Time series model estimation results

\begin{tabular}{|c|c|c|c|c|c|c|c|c|c|c|c|c|c|}
\hline \multirow{2}{*}{$\begin{array}{l}\text { Variable } \\
\text { Technology, } \\
\text { by energy } \\
\text { input }\end{array}$} & \multicolumn{6}{|c|}{ Unit generation costs } & \multicolumn{6}{|c|}{ Peak load capacity } & \multirow{2}{*}{$\begin{array}{c}\text { El. price } \\
\text { Av. elec. } \\
\text { price }\end{array}$} \\
\hline & Fuel oil & $\begin{array}{c}\text { Hard } \\
\text { coal }\end{array}$ & Lignite & Geothermal & Hydro & $\begin{array}{c}\text { Natural } \\
\text { gas }\end{array}$ & Fuel oil & Hard coal & Lignite & Geothermal & Hydro & $\begin{array}{c}\text { Natural } \\
\text { gas }\end{array}$ & \\
\hline $\begin{array}{l}\operatorname{ARMA}(p, q) \\
\text { model }\end{array}$ & $\begin{array}{l}p=1 \\
q=0\end{array}$ & $\begin{array}{l}p=1 \\
q=0\end{array}$ & $\begin{array}{l}p=1 \\
q=0\end{array}$ & $\begin{array}{l}p=1 \\
q=1\end{array}$ & $\begin{array}{l}p=2 \\
q=1\end{array}$ & $\begin{array}{l}p=1 \\
q=1\end{array}$ & $\begin{array}{l}p=1 \\
q=0\end{array}$ & $\begin{array}{l}p=1 \\
q=0\end{array}$ & $\begin{array}{l}p=1 \\
q=0\end{array}$ & $\begin{array}{l}p=2 \\
q=1\end{array}$ & $\begin{array}{l}p=1 \\
q=0\end{array}$ & $\begin{array}{l}p=1 \\
q=0\end{array}$ & $\begin{array}{l}p=1 \\
q=0\end{array}$ \\
\hline$\alpha_{0}$ & $\begin{array}{l}6.305 \\
(6.13)\end{array}$ & $\begin{array}{l}6.330 \\
(5.18)\end{array}$ & $\begin{array}{l}4.215 \\
(7.66)\end{array}$ & $\begin{array}{l}2.439 \\
(5.85)\end{array}$ & $\begin{array}{c}1.699 \\
(17.54)\end{array}$ & $\begin{array}{c}3.800 \\
(35.23)\end{array}$ & $\begin{array}{c}788.031 \\
(10.13)\end{array}$ & $\begin{array}{c}244.919 \\
(3.215)\end{array}$ & $\begin{array}{c}-11244.01 \\
(-0.43)\end{array}$ & $\begin{array}{c}14.083 \\
(136.38)\end{array}$ & $\begin{array}{c}-490.348 \\
(-0.19)\end{array}$ & $\begin{array}{c}4123.654 \\
(4.12)\end{array}$ & $\begin{array}{l}6.435 \\
(5.44)\end{array}$ \\
\hline$\alpha_{1}$ & $\begin{array}{l}0.671 \\
(4.89)\end{array}$ & $\begin{array}{l}0.800 \\
(7.46)\end{array}$ & $\begin{array}{l}0.649 \\
(4.75)\end{array}$ & - & $\begin{array}{c}1.758 \\
(17.43)\end{array}$ & $\begin{array}{l}0.475 \\
(4.84)\end{array}$ & $\begin{array}{l}0.727 \\
(6.12)\end{array}$ & $\begin{array}{c}0.904 \\
(10.01)\end{array}$ & $\begin{array}{c}1.014 \\
(37.72)\end{array}$ & $\begin{array}{l}0.542 \\
(2.04)\end{array}$ & $\begin{array}{c}1.085 \\
(17.32)\end{array}$ & $\begin{array}{l}0.817 \\
(8.87)\end{array}$ & $\begin{array}{l}0.822 \\
(7.26)\end{array}$ \\
\hline$\alpha_{2}$ & - & - & - & $\begin{array}{l}0.660 \\
(9.26)\end{array}$ & $\begin{array}{l}-0.924 \\
(-8.87)\end{array}$ & - & - & - & - & $\begin{array}{l}-0.375 \\
(-2.35)\end{array}$ & - & - & - \\
\hline$\beta_{1}$ & - & - & - & - & $\begin{array}{c}-0.951 \\
(-17.03)\end{array}$ & $\begin{array}{c}-0.960 \\
(-38.34)\end{array}$ & - & - & - & $\begin{array}{c}-0.926 \\
(-10.31)\end{array}$ & & - & - \\
\hline$\beta_{2}$ & - & - & - & $\begin{array}{c}-0.990 \\
(-1307.41)\end{array}$ & - & - & - & - & - & - & - & - & - \\
\hline SSR & 96.144 & 50.727 & 31.056 & 17.776 & 9.829 & 5.934 & 355943.8 & 40759.89 & 2371309 & 18.629 & 10605657 & 3392136 & 36.785 \\
\hline AIC & 4.136 & 3.496 & 3.006 & 3.505 & 2.032 & 2.408 & 12.353 & 10.185 & 14.249 & 3.588 & 15.747 & 15.433 & 3.175 \\
\hline SBC & 4.229 & 3.590 & 3.099 & 3.642 & 2.220 & 2.545 & 12.446 & 10.279 & 14.342 & 3.777 & 15.840 & 15.528 & 3.269 \\
\hline $\mathrm{Q}(4)$ & $\begin{array}{c}2.4 \\
(0.502)\end{array}$ & $\begin{array}{c}2.5 \\
(0.469)\end{array}$ & $\begin{array}{c}4.7 \\
(0.193)\end{array}$ & $\begin{array}{c}4.3 \\
(0.117)\end{array}$ & $\begin{array}{c}2.3 \\
(0.129)\end{array}$ & $\begin{array}{c}1.3 \\
(0.515)\end{array}$ & $\begin{array}{l}1.361 \\
(0.72)\end{array}$ & $\begin{array}{l}8.486 \\
(0.04)\end{array}$ & $\begin{array}{l}2.794 \\
(0.43)\end{array}$ & $\begin{array}{l}1.750 \\
(0.19)\end{array}$ & $\begin{array}{l}2.899 \\
(0.41)\end{array}$ & $\begin{array}{l}3.489 \\
(0.32)\end{array}$ & $\begin{array}{l}1.458 \\
(0.69)\end{array}$ \\
\hline $\mathrm{Q}(8)$ & $\begin{array}{c}4.2 \\
(0.755)\end{array}$ & $\begin{array}{c}4.6 \\
(0.710)\end{array}$ & $\begin{array}{c}9.3 \\
(0.234)\end{array}$ & $\begin{array}{c}8.8 \\
(0.184)\end{array}$ & $\begin{array}{c}2.9 \\
(0.711)\end{array}$ & $\begin{array}{c}5.8 \\
(0.444)\end{array}$ & $\begin{array}{l}9.929 \\
(0.19)\end{array}$ & $\begin{array}{l}9.488 \\
(0.22)\end{array}$ & $\begin{array}{l}7.471 \\
(0.38)\end{array}$ & $\begin{array}{l}4.406 \\
(0.49)\end{array}$ & $\begin{array}{l}6.874 \\
(0.44)\end{array}$ & $\begin{array}{l}7.079 \\
(0.42)\end{array}$ & $\begin{array}{l}1.848 \\
(0.97)\end{array}$ \\
\hline
\end{tabular}

Notes: $t$-values (coefficient estimates) and p-values (Q-statistics) in brackets. SSR is the sum of squared residuals, AIC the Akaike Information Criteria, SBC the Schwarz-Bayesian

Criteria, and Q(4) and Q(8) the Ljung-Box Q-statistics at lags 4 and 8 for the null hypothesis that there is no autocorrelation up to lag $k$. 
Table A.2. Root mean squares forecasting errors (RMSFE)

\begin{tabular}{|c|c|c|c|c|c|c|c|c|c|c|c|c|c|}
\hline Variable & & & Unit g & eration costs & & & & & Peak & ad capacity & & & El. price \\
\hline $\begin{array}{l}\text { Technology, } \\
\text { by energy } \\
\text { input }\end{array}$ & Fuel oil & Hard coal & Lignite & Geothermal & Hydro & Natural gas & Fuel oil & Hard coal & Lignite & Geothermal & Hydro & Natural gas & $\begin{array}{l}\text { Av. el. } \\
\text { price }\end{array}$ \\
\hline $\begin{array}{l}\operatorname{ARMA}(\phi, q) \\
\text { model }\end{array}$ & $\begin{array}{l}p=1 \\
q=0\end{array}$ & $\begin{array}{l}p=1 \\
q=0\end{array}$ & $\begin{array}{l}p=1 \\
q=0\end{array}$ & $\begin{array}{l}p=1 \\
q=1\end{array}$ & $\begin{array}{l}p=2 \\
q=1\end{array}$ & $\begin{array}{l}p=1 \\
q=1\end{array}$ & $\begin{array}{l}p=1 \\
q=0\end{array}$ & $\begin{array}{l}p=1 \\
q=0\end{array}$ & $\begin{array}{l}p=1 \\
q=0\end{array}$ & $\begin{array}{l}p=2 \\
q=1\end{array}$ & $\begin{array}{l}p=1 \\
q=0\end{array}$ & $\begin{aligned} p & =1 \\
q & =0\end{aligned}$ & $\begin{array}{l}p=1 \\
q=0\end{array}$ \\
\hline 1-step & 1.790 & 1.300 & 1.017 & 1.127 & 0.582 & 0.651 & 108.926 & 36.860 & 281.147 & 1.114 & 594.577 & 475.544 & 1.107 \\
\hline Multi-step & 2.345 & 2.163 & 1.256 & 1.482 & 1.252 & 1.244 & 176.122 & 81.491 & 555.436 & 1.325 & 2605.432 & 459.721 & 2.056 \\
\hline
\end{tabular}


Table A.3. Unit root testing

\begin{tabular}{|c|c|c|c|c|c|}
\hline Variable & $\mathrm{ADF}$ & PP & Variable & $\mathrm{ADF}$ & PP \\
\hline plc_fueloil & $\begin{array}{c}-2.303(\mathrm{c}, 0) \\
(0.1175)\end{array}$ & $\begin{array}{c}-2.439(c, 3) \\
(0.1402)\end{array}$ & $\Delta p l c$ fueloil & $\begin{array}{c}-5.417^{* * *}(\mathrm{c}, 0) \\
(0.0001)\end{array}$ & $\begin{array}{c}-5.417^{* * * *}(\mathrm{c}, 0) \\
(0.0001)\end{array}$ \\
\hline plc_hardcoal & $\begin{array}{c}-1.4015(\mathrm{c}, 2) \\
(0.5672)\end{array}$ & $\begin{array}{c}-1.1226(\mathrm{c}, 2) \\
(0.6936)\end{array}$ & $\Delta$ plc_hardcoal & $\begin{array}{c}-2.613(\mathrm{c}, 1) \\
(0.1022)\end{array}$ & $\begin{array}{c}-6.4651 * * *(c, 2) \\
(0.0000)\end{array}$ \\
\hline plc_lignite & $\begin{array}{c}-2.320(\mathrm{c}, \mathrm{t} ; 0) \\
(0.4112)\end{array}$ & $\begin{array}{c}-2.304(\mathrm{c}, \mathrm{t} ; 1) \\
(0.4193)\end{array}$ & $\Delta$ plc_lignite & $\begin{array}{c}-5.641 * * *(c, 0) \\
(0.0001)\end{array}$ & $\begin{array}{c}-5.635^{* * *}(\mathrm{c}, 2) \\
(0.0001)\end{array}$ \\
\hline plc_geoth & $\begin{array}{c}-4.115^{* * *}(\mathrm{c}, 0) \\
(0.0069)\end{array}$ & $\begin{array}{c}-4.084 * * *(\mathrm{c}, 1) \\
(0.0073)\end{array}$ & $\Delta p l l_{\text {_geoth }}$ & $\begin{array}{c}-5.172 * * *(\mathrm{c}, \mathrm{t} ; 1) \\
(0.0056)\end{array}$ & $\begin{array}{c}-17.345^{* * *}(\mathrm{c}, \mathrm{t} ; 14) \\
(0.0001)\end{array}$ \\
\hline plc_bydro & $\begin{array}{c}1.362(\mathrm{c}, 0) \\
(0.998)\end{array}$ & $\begin{array}{c}1.755(\mathrm{c}, 1) \\
(1.000)\end{array}$ & $\Delta p l c \_b y d r o$ & $\begin{array}{c}-5.430 * * *(c, 0) \\
(0.0001)\end{array}$ & $\begin{array}{c}-5.490 * * *(c, 3) \\
(0.001)\end{array}$ \\
\hline plc_ngas & $\begin{array}{c}-2.772 *(c, 2) \\
(0.089)\end{array}$ & $\begin{array}{c}-2.226(\mathrm{c}, 2) \\
(0.206)\end{array}$ & $\Delta p l c \_n g a s$ & $\begin{array}{c}-5.355^{* * *}(\mathrm{c}, \mathrm{t} ; 0) \\
(0.0043)\end{array}$ & $\begin{array}{c}-12.133^{* * *}(\mathrm{c}, \mathrm{t} ; 13) \\
(0.000)\end{array}$ \\
\hline ugc_fueloil & $\begin{array}{c}-2.398(c, 0) \\
(0.1508)\end{array}$ & $\begin{array}{c}-2.314(c, 4) \\
(0.1743)\end{array}$ & $\Delta u g c$ fueloil & $\begin{array}{c}-5.139 * * *(\mathrm{c}, 0) \\
(0.0002)\end{array}$ & $\begin{array}{c}-5.638^{* * *}(\mathrm{c}, 13) \\
(0.0001)\end{array}$ \\
\hline ugc_hardcoal & $\begin{array}{c}-1.892(\mathrm{c}, 0) \\
(0.3312)\end{array}$ & $\begin{array}{c}-2.009(\mathrm{c}, 3) \\
(0.2815)\end{array}$ & $\Delta u g c \_h a r d c o a l$ & $\begin{array}{c}-5.673^{* * *}(\mathrm{c}, 0) \\
(0.0001)\end{array}$ & $\begin{array}{c}-5.665^{* * *}(\mathrm{c}, 2) \\
(0.0001)\end{array}$ \\
\hline ugc_lignite & $\begin{array}{c}-2.565(\mathrm{c}, 0) \\
(0.1112)\end{array}$ & $\begin{array}{c}-2.565(\mathrm{c}, 0) \\
(0.1112)\end{array}$ & $\Delta u g c$ lignite & $\begin{array}{c}-6.824^{* * *}(\mathrm{c}, 0) \\
(0.0000)\end{array}$ & $\begin{array}{c}-7.015^{* * *}(\mathrm{c}, 4) \\
(0.0000)\end{array}$ \\
\hline ugc_geoth & $\begin{array}{c}-11.109 * * *(\mathrm{c}, 3) \\
(0.0000)\end{array}$ & $\begin{array}{c}-3.642 * *(c, 4) \\
(0.0192)\end{array}$ & $\Delta u g c$ geoth & $\begin{array}{c}-5.360^{* * *}(\mathrm{c}, 0) \\
(0.0012)\end{array}$ & $\begin{array}{c}-5.360^{* * *}(\mathrm{c}, 0) \\
(0.0012)\end{array}$ \\
\hline$u g c$ bydro & $\begin{array}{c}-2.210(c, 1) \\
(0.2070)\end{array}$ & $\begin{array}{c}-1.773(c, 1) \\
(0.3859)\end{array}$ & $\Delta u g c \_b y d r o$ & $\begin{array}{c}-4.098^{* * *}(\mathrm{c}, 0) \\
(0.0036)\end{array}$ & $\begin{array}{c}-4.077^{* * *}(\mathrm{c}, 2) \\
(0.0038)\end{array}$ \\
\hline ugc_ngas & $\begin{array}{c}-10.895^{* * *}(\mathrm{c}, 2) \\
(0.0000)\end{array}$ & $\begin{array}{c}-1.524(c, 4) \\
(0.4927)\end{array}$ & $\Delta u g c \_n g a s$ & $\begin{array}{c}-3.053^{*}(\mathrm{c}, 1) \\
(0.0581)\end{array}$ & $\begin{array}{c}-3.764^{* *}(\mathrm{c}, 0) \\
(0.0166)\end{array}$ \\
\hline$P_{e l}$ & $\begin{array}{c}-2.698(\mathrm{c}, \mathrm{t} ; 0) \\
(0.2442)\end{array}$ & $\begin{array}{c}-2.698(\mathrm{c}, \mathrm{t} ; 0) \\
(0.2442)\end{array}$ & $\Delta P_{e l}$ & $\begin{array}{c}-4.999 * * *(\mathrm{c} ; 0) \\
(0.0004)\end{array}$ & $\begin{array}{c}-4.992^{* * *}(\mathrm{c} ; 2) \\
(0.0004)\end{array}$ \\
\hline
\end{tabular}

Notes: ADF $=$ Augmented Dickey Fuller test; PP $=$ Phillips-Perron test; *** $=$ significance at the $1 \%$ level, ${ }^{* *}$ at the $5 \%$ level, $*$ at the 10\% level; geoth = geothermal; ngas = natural gas; in brackets: $\mathrm{c}=$ constant included; $\mathrm{t}=$ trend included; the number gives the lag length (ADF) or bandwidth (PP) used, respectively. For the ADF, the lag length has been chosen based on the SIC, and for the PP Newey-West using the Bartlett kernel is used. ADF/PP test statistics in italics: one or more coefficient estimates in the test equation were statistically not significant. 


\section{CEPE Reports}

Aebischer B. (1999), Veränderung der Elektrizitätskennzahlen im Dienstleistungssektor in der Stadt Zürich und im Kanton Genf. CEPE Report Nr. 1, Zürich, November.

Filippini M., Wild J., and Luchsinger C. (2001), Regulierung der Verteilnetzpreise zu Beginn der Marktöffnung; Erfahrungen in Norwegen und Schweden; Studie im Auftrag des Bundesamtes für Energie. CEPE Report Nr. 2, Zürich, Juli.

Aebischer B. and Huser A. (2002), Energiedeklaration von Elektrogeräten; Studie im Auftrag des Bundesamtes für Energie. CEPE Report Nr. 3, Zürich, Januar.

\section{CEPE Working Papers}

1999

Scheller A. (1999), Researchers' Use of Indicators. Interim Report of The Indicator Project. CEPE Working Paper No. 1, Centre for Energy Policy and Economics (CEPE), Zurich, September.

Pachauri S. (1999), A First Step to Constructing Energy Consumption Indicators for India. Interim Report of the Indicator Project. CEPE Working Paper No. 2, Centre for Energy Policy and Economics (CEPE), Zurich, September.

Goldblatt D. (1999), Northern Consumption: A Critical Review of Issues, Driving Forces, Disciplinary Approaches and Critiques. CEPE Working Paper No. 3, Centre for Energy Policy and Economics (CEPE), Zurich, September.

2000

Aebischer B. und Huser A. (2000), Monatlicher Verbrauch von Heizöl extra-leicht im Dienstleistungssektor. CEPE Working Paper Nr. 4, Zürich, Centre for Energy Policy and Economics (CEPE), September.

Filippini M. and Wild J. (2000), Regional Differences in Electricity Distribution Costs and their Consequences for Yardstick Regulation of Access Prices. CEPE Working Paper No. 5 , Centre for Energy Policy and Economics (CEPE), Zurich, May.

Christen K., Jakob M., und Jochem E. (2000), Grenzkosten bei forcierten Energiesparmassnahmen in Bereich Wohngebäude - Konzept vom 7.12.00. CEPE Working Paper Nr. 6, Centre for Energy Policy and Economics (CEPE), Zürich, Dezember.

2001

Luchsinger C., Wild J., and Lalive R. (2001), Do Wages Rise with Job Seniority? - The Swiss Case. CEPE Working Paper No. 7, Centre for Energy Policy and Economics (CEPE), Zurich, March.

CEPE Reports and CEPE Working Papers can mostly be downloaded free of charge in pdf-format from the CEPE Website (www.cepe.ethz.ch). Alternatively, they may be ordered from: CEPE, Secretariat, ETH Zentrum, WEC C12.1, CH-8092 Zurich, Switzerland. 
Filippini M., Wild J., and Kuenzle M. (2001), Scale and Cost Efficiency in the Swiss Electricity Distribution Industry: Evidence from a Frontier Cost Approach. CEPE Working Paper Nr. 8, Centre for Energy Policy and Economics (CEPE), Zurich, June.

Jakob M., Primas A., und Jochem E. (2001), Erneuerungsverhalten im Bereich Wohngebäude - Auswertung des Umfrage-Pretest. CEPE Working Paper Nr. 9, Zürich, Centre for Energy Policy and Economics (CEPE), Oktober.

Kumbaroglu G. and Madlener R. (2001), A Description of the Hybrid Bottom-Up CGE Model SCREEN with an Application to Swiss Climate Policy Analysis. CEPE Working Paper No. 10, Centre for Energy Policy and Economics (CEPE), Zurich, November.

Spreng D. und Semadeni M. (2001), Energie, Umwelt und die 2000 Watt Gesellschaft. Grundlage zu einem Beitrag an den Schlussbericht Schwerpunktsprogramm Umwelt (SPPU) des Schweizerischen National Fonds (SNF). CEPE Working Paper Nr. 11, Centre for Energy Policy and Economics (CEPE), Zürich, Dezember.

\section{2}

Filippini M. and Banfi S. (2002), Impact of the new Swiss Electricity Law on the Competitiveness of Hydropower, CEPE Working Paper No. 12, Centre for Energy Policy and Economics (CEPE), Zurich, January.

Filippini M., Banfi S., and Luchsinger C. (2002), Deregulation of the Swiss Electricity Industry: Implication for the Hydropower Sector, CEPE Working Paper No. 13, Centre for Energy Policy and Economics (CEPE), Zurich, April.

Filippini M., Hrovatin N., and Zoric J. (2002), Efficiency and Regulation of the Slovenian Electricity Distribution Companies, CEPE Working Paper No. 14, Centre for Energy Policy and Economics (CEPE), Zurich, April.

Spreng D., Scheller A., Schmieder B., und Taormina N. (2002), Das Energiefenster, das kein Fenster ist, CEPE Working Paper Nr. 15, Centre for Energy Policy and Economics (CEPE), Zürich, Juni.

Fillippini M. and Pachauri S. (2002), Elasticities of Electricity Demand in Urban Indian Households, CEPE Working Paper No. 16, Centre for Energy Policy and Economics (CEPE), Zurich, March.

Semadeni M. (2002), Long-Term Energy Scenarios: Information on Aspects of Sustainable Energy Supply as a Prelude to Participatory Sessions, CEPE Working Paper No. 17, Centre for Energy Policy and Economics (CEPE), Zurich, Juli.

Müller A. (2002), Finding Groups in Large Data Sets, CEPE Working Paper No. 18, Centre for Energy Policy and Economics (CEPE), Zurich, October.

\section{3}

Farsi M. and Filippini M. (2003), Regulation and Measuring Cost Efficiency with Panel Data Models: Application to Electricity Distribution Utilities, CEPE Working Paper No. 19, Centre for Energy Policy and Economics (CEPE), Zurich, January. 
Banfi S., Filippini M., and Müller A. (2003), Rent of Hydropower Generation in Switzerland in a Liberalized Market, CEPE Working Paper No. 20, Centre for Energy Policy and Economics (CEPE), Zurich, January.

Müller A. and Luchsinger C. (2003), Incentive Compatible Extraction of Natural Resource Rent, CEPE Working Paper No. 21, Centre for Energy Policy and Economics (CEPE), Zurich, January.

Jakob M. and Madlener R. (2003), Exploring Experience Curves for the Building Envelope: An Investigation for Switzerland for 1970-2020, CEPE Working Paper No. 22, Centre for Energy Policy and Economics (CEPE), Zurich, March.

Banfi S., Filippini M., and Hunt, L. C. (2003), Fuel Tourism in Border Regions, CEPE Working Paper No. 23, Centre for Energy Policy and Economics (CEPE), Zurich, March.

Semadeni M. (2003), Energy Storage as an Essential Part of Sustainable Energy Systems: A Review on Applied Energy Storage Technologies, CEPE Working Paper No. 24, Centre for Energy Policy and Economics (CEPE), Zurich, May.

Pachauri S. and Spreng D. (2003), Energy Use and Energy Access in Relation to Poverty, CEPE Working Paper No. 25, Centre for Energy Policy and Economics (CEPE), Zurich, June.

Aruga K. (2003), Differences in Characteristics of Religious Groups in India: As seen from Household Survey Data, CEPE Working Paper No. 26, Centre for Energy Policy and Economics (CEPE), Zurich, August.

Madlener R. and Wickart M. (2003), The Economics of Cogeneration Technology Adoption and Diffusion: A Deterministic Model, CEPE Working Paper No. 27, Centre for Energy Policy and Economics (CEPE), Zurich, December.

Madlener R. (2003), Modelling the Adoption and Diffusion of Decentralised Energy Conversion Technologies with Hazard Rate Models, CEPE Working Paper No. 28, Centre for Energy Policy and Economics (CEPE), Zurich, December.

Madlener R., Robledo C., Muys B., Hektor B., and Domac J. (2003), A Sustainability Framework for Enhancing The Long-Term Success of LULUCF Projects, CEPE Working Paper No. 29, Centre for Energy Policy and Economics (CEPE), Zurich, December.

\section{4}

Madlener R., Kumbaroglu G., and Ediger V. S. (2004), Modeling Technology Adoption as an Irreversible Investment Under Uncertainty: The Case of the Turkish Electricity Supply Industry, CEPE Working Paper No. 30, Centre for Energy Policy and Economics (CEPE), Zurich, February. 